\title{
Exclusivo metropolitano, "superlucros" e acumulação primitiva na Europa pré-industrial
}

André Arruda Villela

\section{RESUMO}

O artigo tem por objetivo analisar o influente modelo do Antigo Sistema Colonial, proposto originalmente por Fernando Novais. Os três elementos constitutivos do modelo - o exclusivo metropolitano, os "superlucros" e o papel destes últimos na industrialização europeia no início da Era Moderna - são criticados. Ao final, conclui-se que o modelo é essencialmente axiomático, demonstrando limitada aderência tanto à teoria econômica quanto à evidência empírica.

Palavras-chave: Brasil; Antigo Sistema Colonial; superlucros; relaçóes anglo-portuguesas; industrialização europeia.

\section{ABSTRACT}

This article seeks to assess the influential model of the Old Colonial System, originally put forth by Fernando Novais. The three elements that make up the model-namely, metropolitan exclusivism, "superprofits", and the latter's role in European industrialization during the Early Modern period - are criticized. In the end, the article concludes that the model is, essentially, axiomatic, bearing scant adherence to either economic theory or empirical evidence.

Keywords: Brazil; Old Colonial System; superprofits; Anglo-Portuguese relations; European industrialization. 


\section{Introdução}

Dentre as interpretaçóes da formação da economia colonial brasileira, aquela associada à obra clássica de Fernando Novais permanece sendo a mais influente ${ }^{1}$. Tributário direto da contribuição pioneira de Caio Prado 2 , o livro de Novais aprofunda a noção de "sentido da colonização" proposta por aquele autor, conferindo-lhe uma "dinâmica", ao inseri-la no quadro mais amplo das transformaçóes econômicas pelas quais passavam os Estados nacionais da Europa no início da Era Moderna ${ }^{3}$. Embora tratando do período de crise do chamado Antigo Sistema Colonial ${ }^{4}$, o trabalho de Novais constitui a explicação mais bem acabada de um verdadeiro modelo (doravante designado como "modelo" do Antigo Sistema Colonial) de funcionamento estrutural - e ao longo de quase todo o período colonial - da economia da América Portuguesa, em sua relação com a metrópole e, desta, com o restante do mundo atlântico (Europa e África).

De forma muito resumida, o modelo originalmente proposto por Novais e posteriormente consagrado na literatura parte da noção de exclusivo (monopólio) conferido a agentes metropolitanos no comércio com as colônias, a partir do qual são extraídos "superlucros". Por sua vez, estes excedentes, canalizados para a Europa - e redistribuídos, no curso das disputas e negociaçóes diplomáticas da época mercantilista, entre os diferentes Estados nacionais - teriam ajudado a promover a acumulação primitiva de capitais no Velho Continente e, em última instância, a passagem para o capitalismo industrial.

O presente artigo tem por objetivo examinar o "modelo" do Antigo Sistema Colonial, avaliando tanto a sua consistência interna como sua aderência à evidência empírica disponível'5. A análise terá por base os três elementos principais daquele modelo, e que dizem respeito ao excedente produzido na colônia, a saber: i. o arranjo que permitiu a sua extração (o exclusivo metropolitano); ii. a forma assumida por este mecanismo de extração (os chamados "superlucros"); e, por fim, a sua destinação última (a acumulação primitiva no capitalismo industrial que surgia na Europa do início da Era Moderna) ${ }^{6}$. Cada um destes elementos será discutido nas três seçôes que se seguem. As principais conclusões são reunidas ao final.

\section{Exclusivo metropolitano}

Os cerca de três séculos de colonização portuguesa na América comportam, como era de se esperar, grande variância no que diz respeito às relaçóes comerciais da metrópole com a colônia. Assim, períodos de relativa liberdade (1530-1571; 1640-49) intercalaram-se com outros em que se tentou estabelecer o exclusivo de fato e restringir a atuação de estrangeiros no comércio com o Brasil. Tal foi o caso durante a Uniấo Ibérica (1580-1640), na longa vigência do regime de frotas (1649-1766) ou, ainda, durante os anos em que foram concedidos privilégios a companhias de comércio (Cia. Geral do Brasil, 1649-62; e as companhias pombalinas, operantes entre 1755 e 1780) ${ }^{7}$.

Em que pese a ampla evidência de que, por vários períodos, Portugal se mostrou incapaz de fazer valer plenamente o seu monopólio sobre o comércio com a colônia, o "modelo" do Antigo Sistema Colonial assume como válida a caracterização do exclusivo como traço definidor das relaçôes comerciais da metrópole com o Brasil ao longo de todo o período colonial (até 1808, para ser mais preciso). Nas palavras de Novais:

O mais comum é a exclusividade do comércio colonial pertencer à classe empresária mercantil da metrópole. Neste caso, trata-se do privilégio de um grupo de empresários, os mercadores da metrópole. Na colônia, esse grupo detém então a exclusividade da compra dos produtos coloniais (isto é, "oligopsônio"), bem como a venda dos produtos europeus no mercado colonial (quer dizer, "oligopólio"): a situação típica do sistema colonial, se quiséssemos classificá-la tecnicamente, seria pois a do "oligopsônio-oligopólio" ou "oligopólio bilateral". ${ }^{8}$ 
Um exame da literatura secundária, contudo, sugere que a mecânica das operaçóes comerciais envolvendo comerciantes metropolitanos e a colônia era mais complexa do que a noção de "oligopsôniooligopólio", enfatizada por Novais, leva a crer. Com efeito, enquanto que o binômio oligopsôniooligopólio parece sugerir uma capacidade absoluta, por parte dos comerciantes da Metrópole, de "sugar" o excedente da colônia (e, com isso, obter superlucros), as descriçóes mais detalhadas do comércio ultramarino revelam um quadro mais variado - e repleto de incertezas - no comércio com o Brasil.

Por exemplo, Dauril Alden resume a aposta (gamble) inerente às operaçóes do conhecido comerciante Francisco Pinheiro nos negócios com a Bahia da seguinte forma:

Tanto a quantidade como os preços dos produtos disponíveis variavam drasticamente dependendo da data de chegada ao porto das frotas de Lisboa, Porto e das ilhas vinicultoras do Atlântico. Se estas se atrasavam, os preços podiam disparar de 50 a 100\% acima dos valores habituais, para logo depois despencarem assim que os navios reapareciam. Se, como seus agentes frequentemente insistiam, Pinheiro conseguisse obter uma permissão especial do Conselho Ultramarino para enviar mercadorias em alta demanda em um navio que chegasse antes das frotas, tanto ele quanto seus agentes podiam obter lucros substanciais. Mas se ele e seus associados interpretassem incorretamente o mercado e despachassem mercadorias nas frotas já repletas de suprimentos fornecidos por seus competidores, o resultado seria um excesso de oferta e ninguém lucraria. Em tempos coloniais, aventurar-se no mercado marítimo, assim como em investimentos em minas ou produçáo de mantimentos, era sempre uma aposta arriscada. ${ }^{9}$

Como se nota, o comércio colonial, embora, em tese, estruturado sob a forma de um "oligopsôniooligopólio" do ponto de vista agregado (ou seja, das entidades "colônia" e "metrópole"), na prática, admitia, sim, concorrência (competitors) entre fornecedores de mercadorias europeias ${ }^{10}$. E desta concorrência, somada ao timing das operaçóes, poderia resultar lucro ou prejuízo.

Também pelo lado dos produtores de artigos tropicais no Brasil, não era o caso de eles, simplesmente, aceitarem os preços e condiçôes impostos por comerciantes metropolitanos ${ }^{11}$. Há ampla evidência, isso sim, de que os preços pagos pelo açúcar e tabaco colonial eram negociados (haggled over) entre produtores e compradores ${ }^{12}$. S. Schwartz, igualmente, mostra de que maneira os donos de engenho baianos procuraram, no século XVII, limitar a expansão da produção de açúcar, como forma de reduzir a oferta e, portanto, evitar queda de preços. Ou ainda, a ajuda dada pela Câmara de Salvador na fixação dos preços do açúcar a ser vendido aos comerciantes ${ }^{13}$. Nada que se assemelhe a uma situação de desvantagem absoluta de produtores coloniais no trato com comerciantes metropolitanos, como dá a entender parcela da historiografia ${ }^{14}$.

Cabe assinalar que, por mais que enfatize o papel crucial do exclusivo metropolitano, a literatura tradicional reconhece, sim, a existência de inúmeros "vazamentos" dentro das relaçóes comerciais Portugal-Brasil, a exemplo das licenças concedidas a navios estrangeiros para comercializar com a colônia e o contrabando ${ }^{15}$. Contudo, no entender destes autores, tais exceçôes não seriam suficientes para pôr em xeque o exclusivo metropolitano. Mais do que isso, para alguns, a concessão de isençóes a estrangeiros, assim como a atividade do contrabando, reforçariam o argumento básico do modelo teórico tradicional, servindo, precisamente, de prova da existência de "superlucros" a serem explorados no comércio direto com o Brasil ${ }^{16}$.

O problema com este argumento é que ele não confirma a existência em si dos superlucros, mas sim de algum nível de renda de monopólio (rents, no linguajar dos economistas), isto é, lucros superiores aos que se verificariam em um cenário (impossível, é claro, em um contexto mercantilista) de livre concorrência ${ }^{17}$. Rendas de monopólio por si só - e não, necessariamente, superlucros - já seriam suficientes para atrair a cobiça estrangeira. Tais rendas, por sua vez, eram esperadas na medida em que a metrópole tentava restringir o comércio da colônia com o exterior a seus comerciantes ou, no máximo, a estrangeiros autorizados. 
Resta saber, porém, em que medida os "vazamentos" acima referidos minavam a capacidade de Portugal, efetivamente, fazer valer (enforce) o exclusivo ${ }^{18}$. Desta capacidade dependia, ao final das contas, o nível de rendas de monopólio extraíveis no comércio com o Brasil. Trata-se, em outras palavras, de distinguir intenção e prática no exercício deste exclusivo - algo crucial, e que os adeptos do "modelo" do Antigo Sistema Colonial nem sempre fazem ${ }^{19}$.

Conforme se argumentou acima, os conceitos de "exclusivo comercial" e oligopólio-oligopsônio não parecem refletir rigorosamente a forma assumida pelo comércio Portugal-Brasil ao longo de três séculos. Embora reconheça a existência de inúmeros vazamentos no comércio colonial, a literatura tradicional os considera insuficientes para reduzir de forma significativa a extração de excedentes da colônia. Em outras palavras, segundo esta interpretação, o Pacto colonial e o exclusivo, em que pesem tais vazamentos, garantiriam a extração de grande parte do excedente colonial, sob a forma dos chamados "superlucros", analisados a seguir.

\section{"Superlucros" 20}

Conforme argumentado acima, o "modelo" do Antigo Sistema Colonial assume implicitamente uma capacidade efetiva da Metrópole em fazer valer o exclusivo comercial, capacidade esta que permitiria a seus comerciantes auferirem lucros extraordinários no trato com o Brasil - os chamados "superlucros". Estes, por sua vez, promoveriam

(...) de um lado, uma transferência de renda real da colônia para a metrópole, bem como a concentração desses capitais na camada empresária ligada ao comércio ultramarino. Reversivamente, detentores da exclusividade da oferta de produtos europeus nos mercados coloniais, os mercadores metropolitanos, adquirindo-os a preços de mercado na Europa, podiam revendê-los na colônia no mais alto preço acima do qual o consumo se tornaria impraticável (...). ${ }^{21}$

Deixando de lado as dúvidas, vistas na seção anterior, quanto a esta capacidade de extração (de excedentes) na prática, como é que são estimados, na literatura, os lucros do comércio colonial?

À primeira vista, a taxa de lucros é conceito livre de maiores controvérsias, representando a relação entre os lucros (receitas - custos) de determinada operação e o capital investido na mesma ${ }^{22}$. Quando se desce ao nível da contabilidade das operaçôes comerciais efetivamente realizadas no início da Era Moderna, porém, as dificuldades começam a surgir. Por exemplo, em uma expedição típica de comércio colonial, freqüentemente juntavam-se armador e investidores passivos. Ao primeiro cabia, como pagamento por seu trabalho de organizaçáo (armaçáo) da expedição, uma comissão a qual não faziam jus os investidores passivos, que adquiriam quotas daquela operação. Tal comissão, é claro, não constitui remuneração do capital eventualmente investido pelo armador, e sim pagamento por seus serviços de armação. Neste sentido, não deve ser incluída entre os componentes dos lucros comerciais. Da mesma forma, o tratamento contábil dispensado às despesas de seguros e capital fixo (dado que o navio utilizado em uma expedição o era em várias outras) também exige cuidado dos pesquisadores modernos ${ }^{23}$.

Para Guillaume Daudin, porém, possivelmente mais importante do que as questôes acima é a atençáo que deve ser dada, nos estudos empíricos sobre a lucratividade do comércio colonial, à cronologia das viagens dos negociantes da época ${ }^{24}$. Conforme nota o autor, o pagamento recebido por investidores nas operaçóes comerciais da França com suas colônias nas Índias Ocidentais, por exemplo, era espaçado ao longo de vários anos, o que exige cuidado adicional do pesquisador na hora de calcular a taxa de lucro efetivamente auferida pelo investidor em determinada operaçáo ${ }^{25}$.

É por este conjunto de razóes que a literatura que trata da rentabilidade de negócios coloniais chega a resultados tão díspares quanto à "taxa de lucros" auferida, por exemplo, no tráfico de escravos, que, dependendo do autor, pode variar de $7 \%$ a $30 \%$ anuais $^{26}$. 
Um dos raros esforços (possivelmente, o único) de mensuração dos lucros obtidos no comércio colonial português com o Brasil se deve a pesquisa realizada por José Jobson Arruda com base nas Balanças do Comércio português referentes ao final do período colonial ${ }^{27}$. Ali, o autor define os lucros como resultando a diferença média entre os preços (CIF) de importação de produtos coloniais por Portugal e sua posterior re-exportação (valores FOB) na Europa. No caminho inverso, o lucro apurado na venda de produtos da Europa no Brasil é medido pela diferença média entre os preços pagos na sua entrada em Portugal (a partir de terceiros mercados) e aqueles obtidos quando da revenda em portos brasileiros ${ }^{28}$.

Os resultados de seus cálculos indicariam taxas de lucro no comércio de Portugal com o Brasil que variavam entre $20 \%$ e $700 \%$ no caso dos produtos trazidos da colônia e $12 \%$ e $75 \%$ naqueles introduzidos no Brasil. Nas palavras do autor:

Comparando o sobrepreço dos produtos de importaçáo com o sobrepreço dos produtos de exportaçáo colonial, chegamos à conclusão de que o lucro maior do comércio português era obtido na revenda dos produtos brasileiros no exterior, e não na venda de produtos europeus ou portugueses na Colônia. Assim mesmo, não podemos considerar desprezível o sobrelucro de $50 \%$ obtido em alguns dos principais produtos de importaçáo colonial. ${ }^{29}$

Ora, o problema reside em que aquilo que Arruda denomina "sobrepreço" (ou "sobrelucro") não é equivalente à taxa de lucros do comércio colonial. Trata-se, na realidade, de uma medida de margem bruta de comercialização (mark up), que serve para cobrir todos os custos do empresário - e não apenas o de compra e transporte de mercadorias. Neste sentido, tais margens superestimam (provavelmente, em muito) a real lucratividade do comércio colonial.

Tome-se o exemplo de produtos levados do Brasil para a Metrópole. Neste caso, os cálculos de Arruda captam apenas as receitas obtidas com a (eventual) venda dos produtos em Portugal, deduzidas dos gastos com a compra das mercadorias nos portos brasileiros (acrescidos de despesas de fretes e comissóes). Porém, tais gastos não constituem os únicos itens de custos na atividade do comerciante metropolitano. E as despesas de capital (embarcações, instalaçôes físicas, empréstimos)? O eventual pagamento por direitos de monopólio arrematados à Coroa? Gastos com pessoal? Pagamento de comissóes a agentes? E as mercadorias que foram transportadas, registradas nos livros dos Balanços de Comércio, mas terminaram por perecer em armazéns no Brasil e Portugal por falta de compradores? Todas estas despesas também teriam que ser cobertas a partir das margens que o importante estudo de Arruda (1980) revela ${ }^{30}$. Resulta daí que o lucro efetivamente obtido pelos comerciantes metropolitanos foi, sem dúvida, muito inferior ao que sugerem suas estimativas ${ }^{31}$.

Neste sentido, torna-se esclarecedora a comparação com as informaçóes disponíveis do comércio ultramarino realizado por outras naçóes europeias à época. O exame do caso da Companhia das Índias Orientais Holandesas (VOC) permite ilustrar os limites das estimativas de Arruda, colocando a discussão sobre os lucros do comércio colonial na Era Mercantilista em termos mais realistas. Assim, no monumental estudo de De Vries e Van der Woude, vê-se que, entre meados do século XVII e final do XVIII, o comércio da VOC entre a Ásia e a Europa proporcionou retornos médios (isto é, margens brutas, à la Arruda) à companhia da ordem de $150 \%{ }^{32}$. Já a rentabilidade da empresa - e este parece ser um melhor indicador dos lucros gerados pelo negócio colonial - variou, no mesmo período, de 3,3\% a 7,9\%, com uma média de $5 \%{ }^{33}$.

Não deixa de ser revelador o fato de que uma companhia sabidamente bem-sucedida ${ }^{34}$ apresentasse uma rentabilidade (sobre o capital) medida em apenas um dígito. A noção de superlucros, ao que tudo indica, náo captura adequadamente a natureza do comércio colonial da época, os riscos envolvidos e os enormes custos em que incorriam os comerciantes metropolitanos.

Nota-se, desde já, que o que vai acima não equivale a afirmar que não havia lucros a serem obtidos no comércio colonial, e sim que tais lucros não eram, necessariamente, extraordinários. É, justamente, 
a esta conclusão que chega Guillaume Daudin ${ }^{35}$. Segundo o autor, investimentos feitos no comércio colonial francês do século XVIII proporcionaram uma taxa de retorno médio sobre o capital de 6\%. Neste sentido, eram alternativa preferível, em termos de rendimento, aos títulos da dívida pública (que pagavam de $4 \%$ a 5,5\%) e da dívida privada (retorno de 5\%); adicionalmente, os investimentos no comércio exibiam combinação de maturidade (curta) e risco (baixo, no caso do risco privado) que os tornavam mais interessantes que as outras modalidades de aplicação à época ${ }^{36}$.

É fato que diversas atividades à época na Europa geravam lucros "normais", isto é, apenas marginalmente inferiores aos lucros advindos das operaçôes de comércio colonial (devido à existência, neste último caso, de algum grau de renda de monopólio). Se tal é o caso, os adeptos do "modelo" se deparam com uma dificuldade adicional, qual seja, demonstrar por que foi a exploração de colônias - e não, por exemplo, os lucros auferidos em atividades como a construção civil, o comércio interno ou a agricultura - quem forneceu os lucros que ajudariam no financiamento da industrializaçáo europeia ${ }^{37}$. Dito de outra forma, a insistência, entre os adeptos do "modelo", em que os lucros coloniais sejam "super" parece derivar da crença de que só assim eles poderiam ter contribuído decisivamente para a industrialização europeia.

Para concluir, se os números de Arruda, efetivamente, superestimam a extensão da lucratividade do comércio colonial, como é que tal resultado afeta a consistência do "modelo"? Antes de uma avaliação mais completa, a ser feita nas Consideraçôes Finais, o artigo discutirá o último - e, possivelmente, mais importante - elemento do 'tripé', envolvendo a acumulação primitiva de capitais e a industrialização europeia.

\section{Acumulação primitiva (e mercados consumidores)}

Conforme salientado na Introdução, o grande mérito da contribuição clássica de Fernando Novais foi integrar o esquema pradiano tradicional a um contexto mais amplo da formação do capitalismo industrial na Europa do início da Era Moderna. Para o autor, esta era a essência, mesmo, da sua noção de "sistema" colonial, na qual se articulavam metrópoles e colônias antes da Revolução Industrial. Em suas palavras:

(...) o sistema colonial mercantilista apresenta-se-nos atuando sobre os dois pré-requisitos básicos da passagem para o capitalismo industrial: efetivamente, a exploração colonial ultramarina promove, por um lado, a primitiva acumulação capitalista por parte da camada empresarial; por outro lado, amplia o mercado consumidor de produtos manufaturados. Atua, pois, simultaneamente, de um lado, criando a possibilidade do surto maquinofatureiro (acumulação capitalista), por outro lado a sua necessidade (expansão da procura dos produtos manufaturados). Criam-se, assim, os pré-requisitos da Revolução Industrial (...). ${ }^{38}$

Eis aí, portanto, o "sentido" último da colonização ultramarina europeia no início da Era Moderna, segundo o "modelo": contribuir para o processo de industrialização da Europa pela via dos lucros e da abertura de mercados consumidores para manufaturados europeus ${ }^{39}$.

A obtenção de lucros no comércio colonial (ou no comércio exterior de forma geral) e seu posterior investimento na atividade manufatureira aparece como uma das formas de "acumulação primitiva" na obra de $\mathrm{Marx}^{40}$, na qual se inspira o "modelo". Não obstante, a própria idéia de que o capitalismo necessitou de uma acumulação prévia de capital para se desenvolver é questionada por economistas nãomarxistas, seja do ponto de vista teórico como empiricamente.

De fato, conforme lembra Deirdre McCloskey, há décadas a teoria econômica moderna vem colocando em segundo plano o papel da acumulaçáo de capital físico para explicar o crescimento econômico, preferindo destacar, em seu lugar, fatores relacionados ao progresso técnico e à inovação. Adicionalmente, a autora nota que a acumulação havida ao longo de séculos não poderia, por definição, ter contribuído com a Revolução Industrial do final do século XVIII, dado que o capital se depreciaria com o passar do tempo ${ }^{41}$. 
Quanto à evidência histórica em torno da acumulaçáo primitiva de capital, a autora, primeiramente, chama atenção para o fato de não haver indícios de que os europeus se tornaram mais poupadores (acumuladores) no início da Era Moderna, ou que apenas no século XVIII passou a haver recursos suficientes para o investimento industrial (e o take-off rumo ao capitalismo). A rigor, argumenta, os europeus sempre foram forçados a ser poupadores, tendo que se abster, por exemplo, de consumir parte significativa de sua safra anual de grãos (e, muitas vezes, passar fome como decorrência) a fim de reservar sementes para o plantio da safra seguinte ${ }^{42}$.

McCloskey cita, ademais, estimativas de Charles Feinstein dando conta de que a taxa de investimento em capital físico na Grã Bretanha (4\% do PIB) era menor que a média da Europa (11\%) em 1700, subindo para 6\% (12\%) em 1760 e 8\% (12\%) em $1800^{43}$. Tais estimativas, inclusive, seriam mais compatíveis com dois outros resultados da pesquisa histórica das últimas décadas, a saber: os baixos requisitos de capital fixo nas primeiras plantas têxteis da Revolução Industrial e, associado a isso, o fato de as necessidades de capital dos empresários pioneiros terem sido atendidas, primordialmente, por lucros retidos e crédito comercial ${ }^{44}$. Ao que parece, portanto, a "acumulação" (poupança) não foi um limitador para a industrialização britânica ${ }^{45}$.

Ainda assim - e supondo que, ao contrário do que afirma McCloskey, a noção de "acumulação primitiva” seja, mesmo, útil do ponto de vista teórico e também empiricamente válida para se entender a origem da industrialização europeia -, como é que o "modelo" do Antigo Sistema Colonial explica o fato sabido de que Portugal iria se industrializar apenas muito tardiamente? Aqui, Novais e outros recorrem ao longo histórico de relaçóes diplomáticas Portugal-Inglaterra no início da Era Moderna para sugerir que os diversos acordos que a Coroa lusa foi levada a firmar com os ingleses em troca de proteção militar terminaram por assegurar que o beneficiário último da exploração do Brasil fosse a Inglaterra ${ }^{46}$. Assim, sucedem-se em Portugal e Brasil na Crise do Antigo Sistema Colonial referências à "aliança inglesa" (páginas 18, 19 e 49); "troca de aliança e mesmo proteção política por vantagens comerciais crescentes" (página 20); "amplas regalias concedidas aos comerciantes ingleses" (página 22); "enormes vantagens comerciais" (página 23); e, finalmente, ao conhecido Tratado de Methuen, de 1703 (páginas 24, 27, 29 e 43).

Efetivamente, as relaçôes diplomáticas de Portugal, pelo menos desde a Restauração (1640), foram condicionadas pelo imperativo de assegurar sua soberania e a de suas possessôes no ultramar (bem como a segurança da navegação e das rotas comerciais) em meio às acirradas disputas envolvendo naçóes mais poderosas em seu entorno, a exemplo das potências terrestres (França e Espanha) e marítimas (Grã Bretanha e Holanda). É no contexto de tal restrição que se deve abordar os tratados firmados entre Portugal e Inglaterra em 1642, 1654, 1661 e, mais ainda, o Tratado de Methuen, de $1703^{47}$.

No caso do tratado de 1642, o apoio inglês à Restauraçáo teve como contrapartida a abertura do mercado português e de suas possessôes na África e Índia a navios ingleses, ao mesmo tempo em que conferia privilégios aos comerciantes ingleses em Portugal ${ }^{48}$. Em 1654, novo acordo era firmado com a Inglaterra, em meio a guerra entre Portugal e a Espanha. Segundo Leonor Freire Costa, este tratado facilitou a infiltração dos interesses ingleses na América portuguesa, sobretudo na Bahia e Rio de Janeiro, onde se encontrava a produção do açúcar, artigo de maior importância nas exportaçóes de Portugal para a Inglaterra ${ }^{49}$. No mesmo tratado, Portugal abria mão de seu direito soberano de cobrar tarifas de importação conforme sua vontade, ao fixar um teto de 23\% (10\% a título de décima, 10\% de sisa e 3\% de consulado) para as taxaçóes que recairiam sobre as importaçóes inglesas - e, mesmo assim, cobradas em cima de mercadorias avaliadas a um preço inferior ao verdadeiro ${ }^{50}$. Adicionalmente, estipulava-se que estes termos somente poderiam ser alterados com o consentimento de dois comerciantes ingleses indicados pelo cônsul daquele país ${ }^{51}$.

Já o Tratado de 1661, assinado por ocasiāo do casamento de Carlos II da Inglaterra com Catarina de Bragança, irmã do Rei Afonso VI de Portugal, confirmou os dois tratados anteriores e incluiu - 
crucialmente, para Portugal - uma cláusula secreta segundo a qual a Inglaterra garantia apoio contra a Espanha e se comprometia a defender as colônias portuguesas contra todos os seus inimigos ${ }^{52}$. Em contrapartida desta proteçáo, Portugal cedeu o porto de Bombaim à Inglaterra, ato que "(...) adquire uma dimensão ofensiva contra os Estados Gerais”, inimigos de ambos ${ }^{53}$. Já o casamento em si exigiu o pagamento de um dote de 2 milhóes de cruzados (equivalentes a um ano de arrecadaçáo da décima, em Portugal), além da concessão de Tânger à Inglaterra que, juntamente com a nova possessão na Índia, adquiria dois pontos de entrada cruciais no norte da África e na Ásia ${ }^{54}$.

É no Tratado (comercial) de Methuen, porém, que a literatura concentra a maior parte de suas atençóes. Firmado em dezembro de 1703, sucedeu dois tratados homônimos, de natureza política, negociados em meio à crise em torno da sucessão ao trono espanhol.

Prejudicados pelas pragmáticas portuguesas (leis suntuárias, que coibiam o uso de roupas feitas a partir de panos de luxo, tipicamente importados) da segunda metade do século XVII, comerciantes de panos de lá da Inglaterra começaram a discutir, pelo menos desde 1677, formas de propor a Portugal um novo tratado ou revisão dos termos acordados em 1654 entre os dois países, mas sem sucesso ${ }^{55}$. Enviado a Lisboa como negociador em 1702, John Methuen esteve à frente das discussóes que desembocariam na assinatura dos três tratados no ano seguinte. Os dois primeiros, datados de maio de 1703 (e assinados por seu filho, Paul), serviram para tirar Portugal de sua neutralidade e garantir a sua adesão formal à Grande Aliança (composta pela Inglaterra, Holanda, o Sacro Império e o Ducado de Sabóia) ${ }^{56}$. O terceiro tratado - comercial - revogou, na prática, as proibiçóes presentes nas leis suntuárias portuguesas e restabeleceu a permissáo para a entrada de artigos de lá ingleses, taxados à alíquota de $23 \%$ estabelecida pelo tratado de 1654 .

Tendo em vista a controvérsia que, após mais de três séculos, o Tratado de Methuen ainda provoca dentro da historiografia brasileira e portuguesa ${ }^{57}$, passa muitas vezes despercebido o quáo sucinto foi o diploma acordado entre o embaixador inglês e os portugueses, composto que foi de apenas três artigos. Pelo primeiro, Portugal concordava em voltar a admitir no Reino os artigos manufaturados de lá ingleses (apenas eles), que haviam sido proibidos pelas pragmáticas, no bojo do esforço de desenvolvimento manufatureiro português capitaneado pelo Conde de Ericeira no último quartel do séc. XVII ${ }^{58}$. Em contrapartida (Art. 2o), a Rainha Anne obrigava-se a admitir, dali em diante, o ingresso de vinhos portugueses na Inglaterra, pagando alíquota de importação $1 / 3$ inferior à cobrada sobre o vinho francês. $\mathrm{O}$ Artigo $3^{\text {o }}$ rezava que "Os Exmos. Senhores Plenipotenciários prometem, e tomão sobre si, que seus Amos acima mencionados ratificarão este Tratado, e que dentro do termo de dois meses se passarão as Ratificaçóes" 59 .

Como se nota, a leitura dos termos do Tratado não dá pistas dos mecanismos concretos que teriam permitido aos lucros do comércio com o Brasil transformarem-se em investimentos na Inglaterra (Grã Bretanha a partir de 1707), conforme enfatizado pelos adeptos do "modelo". Assim, apresentá-lo como evidência cabal de instrumento que assegurou a transferência, para a Inglaterra, dos lucros portugueses obtidos no comércio com o Brasil é claramente insatisfatório. Para tanto, seria necessário demonstrar de que forma o comércio entre duas naçóes soberanas promoveu tal transferência.

Recorrer, como faz Eduardo Mariutti, à noção, tomada emprestada a Immanuel Wallerstein, de "semiperiferia" para designar a posição de Portugal - simultaneamente "centro" do Brasil e "periferia" da Inglaterra - no "sistema-mundo" da Era Mercantilista tampouco faz avançar este argumento:

Assim, a preservação da aliança com a Inglaterra (...) permitiu que os rendimentos provenientes do Império Português fossem canalizados para outra metrópole que, além de deter um vasto e diversificado império, passou a ter acesso aos recursos gerados nas colônias sem o ônus de administrá-las. Isso acelerou a acumulação primitiva de capitais e ajudou a promover a industrialização britânica (ênfase no original). ${ }^{60}$

De fato, tem-se a impressão de se estar diante de uma "solução" ad hoc, incapaz de trazer elementos que ajudem a compreender a maneira efetiva por meio da qual as relaçóes metrópole-colônia entre 
Portugal e o Brasil terminavam por ajudar na industrialização britânica. Afinal, qual(is) o(s) mecanismo(s) por trás desta "triangulação" Brasil-Portugal-Inglaterra que teriam "ajudado a promover a industrialização" nesta última? Os (super?) lucros do comércio com o Brasil? Será que tais “superlucros” existiram, de fato? Em caso afirmativo, como é que eles eram, em última instância, apropriados pelos britânicos? E se, efetivamente, deu-se esta transferência (e em nenhuma parte da literatura encontra-se evidência factual neste sentido - sequer a tentativa de demonstrá-la), em que medida tais lucros teriam sido decisivos para financiar a indústria na Grã Bretanha? ${ }^{61}$

Não são poucas as questôes suscitadas - mas não respondidas - pelo "modelo" quanto aos reais efeitos dos tratados de 1703. Uma avaliação mais rigorosa destes impactos exige que se examine náo apenas o contexto geopolítico em que a aliança anglo-portuguesa foi forjada como também o comportamento dos fluxos comerciais e da produção industrial nos dois países ao longo do século XVIII. O restante desta seção é dedicado, justamente, a tais questôes.

Começando pela dimensão diplomática, é consensual que a fragilidade da posição de Portugal ao longo dos séculos de intensa rivalidade entre os Estados nacionais europeus levou o país a firmar acordos sob condiçôes desvantajosas. Este foi, claramente, o caso do Tratado de 1654, concedendo inúmeros privilégios aos comerciantes ingleses, sem que Portugal obtivesse vantagens palpáveis em retorno. Porém, tal não foi, definitivamente, o ocorrido nos tratados de 1661 e 1703, os quais incluíam disposiçóes obrigando a Inglaterra a assumir responsabilidade concreta pela defesa da integridade do território português e de suas possessóes no além-mar, “(...) mercê da abertura do espaço econômico português" 62 . O valor - militar e econômico - para Portugal de tal garantia não pode ser desprezado em qualquer avaliação dos custos e benefícios dos Tratados de 1703.

No caso particular do Tratado de Methuen assinado em dezembro, ou seja, o tratado comercial, seu resultado concreto para Portugal foi forçar o fechamento da maior parte de suas manufaturas de lá, manufaturas essas que gozavam, até o final do século, da proteção (parcial) conferida pelas pragmáticas. Tal fato, porém, está longe de configurar sinônimo de um "pecado original” na história de Portugal, instante inicial de seu conhecido atraso econômico ${ }^{63}$. Conforme nota Jorge Pedreira, os efeitos deletérios do Tratado se concentraram, principalmente, sobre os setores mais modernos (lanifícios) do tecido industrial português, que atendiam a um mercado urbano mais sofisticado (e reduzido) e sofriam a concorrência direta dos importados. As manufaturas rurais, por sua vez, compostas de artesãos e pequenas oficinas produtoras de panos mais grosseiros, sapatos, artigos de madeira, metal, couro etc., atendendo mercados locais, mais pobres (e que atingiam a maior parte da população portuguesa), foram pouco afetadas tanto pelas políticas protecionistas de Ericeira como pelo Tratado de $1703^{64}$.

Note-se, ademais, que o Tratado de Methuen não impedia que o governo português continuasse a estimular as manufaturas domésticas, ainda que tornasse mais difíceis tais políticas ${ }^{65}$. A conjuntura internacional que norteara as políticas anteriores de substituição de importaçôes havia mudado, porém. Deixava de prevalecer, na mesma magnitude, a escassez de metais preciosos que caracterizou o último quarto do século XVII e que, em parte, motivara as pragmáticas de então. Beneficiado pela recuperação do comércio colonial, pelo ingresso adicional de prata proporcionado pelas atividades de contrabando na região da Colônia de Sacramento e com os ganhos decorrentes do contrato de asiento (permitindo a colocaçáo de escravos nos mercados da América espanhola), as prioridades passaram a ser outras. A atenção do governo voltava-se, mais uma vez, à "vocação" histórica de Portugal enquanto entreposto comercial entre a Europa e os trópicos. A partir de então, Portugal procurou reforçar o Pacto Colonial e nacionalizar o comércio ultramarino, objetivos tornados mais urgentes diante da notícia das descobertas de ouro nas Gerais ${ }^{66}$.

E o que se pode dizer da repercussão dos Tratados de Methuen na Inglaterra? Curiosamente, o tratado comercial passou despercebido da opinião pública inglesa contemporânea, comparativamente aos tratados de aliança política do mesmo ano. Para tal, teriam contribuído tanto o desejo de não 
antagonizar a Holanda, principal concorrente da Inglaterra no mercado português, como o receio de encontrar oposição no Parlamento ao que poderia ser interpretado como usurpação, pela Rainha, da prerrogativa parlamentar de legislar sobre matéria de ordem tributária ${ }^{67}$. Dez anos mais tarde, o Tratado - e Methuen em pessoa - ganhariam notoriedade, em meio às negociaçóes em torno de um acordo de livre comércio anglo-francês em Utrecht que, na prática, representaria o fim dos termos pactuados em 1703. Contudo, a oposição organizada do wool interest na Inglaterra, com a possível ajuda de negociadores portugueses presentes em Utrecht, terminou por sepultar o acordo com a França e garantir a continuidade das relaçóes comerciais anglo-portuguesas em bases privilegiadas para a Gră Bretanha ${ }^{68}$.

Quanto aos efeitos do Tratado sobre o fluxo comercial entre os dois países, eles foram, sem dúvida, notáveis: a soma de exportaçóes e importaçôes no comércio bilateral dobrou, passando de pouco menos de $£ 1$ milhão em 1703 para um pico de $£ 1,9$ milhão em 1757, recuando (com oscilaçôes) a partir daí até o final do século. As importaçóes portuguesas provenientes da Inglaterra saíram de uma média de $£ 355$ mil no qüinqüênio anterior ao Tratado para pouco mais de $£ 1$ milhão em 1730 , com um pico de $£ 1,6$ milhão em 1757. Suas exportações, enquanto isso, situaram-se, em média, em torno de $£ 400$ mil/ano, duas vezes mais que o valor alcançado nos cinco anos que antecederam Methuen ${ }^{69}$. Durante a maior parte do período, portanto, a balança bilateral foi deficitária do lado português, e tornar-se-ia superavitária apenas em $1798^{70}$.

O déficit, aliás, teria caracterizado as relaçóes comerciais de Portugal com seus principais parceiros à época. Segundo um contemporâneo, Arthur Stert, durante o auge da ascendência comercial britânica em Portugal o país apresentaria saldos negativos nas transações com todas as naçóes ${ }^{71}$. Este era, certamente, o caso do comércio de Portugal com a França (equivalente a cerca de 1/4 do comércio angloportuguês), deficitário em quase todos os anos entre 1716 e $1780^{72}$.

O padrão recorrente de déficits comerciais de Portugal com outros parceiros que não a Inglaterra ao longo do século XVIII sugere que outros fatores, além do próprio Tratado, operaram no sentido de possibilitar o aumento das importaçóes portuguesas em ritmo superior ao de suas vendas no exterior ${ }^{73}$. Neste sentido, um candidato óbvio a variável explicativa adicional é a disponibilidade de ouro brasileiro, instrumento último de financiamento dos déficits lusos ${ }^{74}$. Não causa surpresa, portanto, que o início da tendência de queda das importaçôes portuguesas oriundas da Inglaterra, na década de 1750, coincida com o declínio da produção aurífera brasileira e, portanto, com a maior dificuldade de Portugal financiar seus déficits em conta corrente ${ }^{75}$.

O ouro brasileiro constitui caso em que, inequivocamente, o comércio Portugal-Brasil-Inglaterra foi importante no século XVIII, mas não em um sentido de "exploração" por parte de europeus (a não ser que se considere a cobrança do quinto real sobre a produção de ouro no Brasil extorsiva). Grande parte deste ouro terminou por afluir - pela via comercial - aos cofres do Banco da Inglaterra, ajudando na adoção de um padrão bimetálico naquele país após 1717 e um padrão-ouro de fato em 1774, quando os pagamentos em prata foram limitados a $£ 25^{76}$. Levando-se em conta, adicionalmente, que as operaçóes de desconto de letras de câmbio praticadas pelo Banco em favor de grandes comerciantes individuais e companhias de comércio (que mantinham contas naquela instituição e recebiam empréstimos em notas conversíveis) ajudaram no desenvolvimento de um mercado de crédito que supriria parte das demandas por financiamento dos empresários industriais britânicos, aí, sim, encontra-se um elo (o ouro) - ainda que muito indireto - entre o comércio Brasil-Portugal e a Revolução Industrial britânica. Curiosamente, porém, são raras as referências na literatura brasileira a este canal ligando a América portuguesa à história econômica da Inglaterra no séc. XVIII ${ }^{77}$.

E quanto aos impactos do Tratado comercial de 1703 sobre a economia "real" (isto é, não monetária) da Inglaterra? O "modelo" do Antigo Sistema Colonial também assume, implicitamente, que o aumento verificado nas exportaçóes de manufaturados de lã para Portugal (e, por extensão, o Brasil) na primeira metade do século XVIII teve papel significativo na industrialização da Grã Bretanha no período ${ }^{78}$. Este 
é o segundo "sentido" da colonização enfatizado por seus adeptos, qual seja, abrir novos mercados consumidores para os manufaturados europeus.

Como avaliar o mérito de tal afirmativa? De início, cabe notar que o ramo de artigos à base de lá (woolens) era o mais importante, individualmente, na indústria britânica durante a maior parte do século XVIII, respondendo por cerca de $1 / 3$ do valor da produçáo industrial em 1700 e 1/4 em $1760^{79}$. A partir daí, seu peso relativo decaiu ainda mais, cedendo espaço ao setor metalúrgico e, mais ao final do século, aos artigos têxteis de algodão. Em termos absolutos, porém, a produção de artigos de lã continuou a crescer, acumulando expansão de mais de $250 \%$ ao longo do século ${ }^{80}$.

No início do século XVIII os woolens representavam $85 \%$ do valor das exportaçóes de manufaturados da Grã Bretanha (ou 69\% das exportaçôes totais, estimadas em cerca de $£ 4,3$ milhóes), proporção esta que recuou para 49\% em 1772-4 (43\% das exportaçôes totais $)^{81}$. Ao mesmo tempo, os artigos manufaturados de lá - aqueles, efetivamente, beneficiados pelos termos do Tratado de Methuen - representaram, consistentemente, entre $70 \%$ e $80 \%$ das importaçóes portuguesas provenientes da Gră Bretanha ao longo da maior parte do século XVIII ${ }^{82}$.

Quando do início da vigência do Tratado, as importaçôes portuguesas de woolens britânicos correspondiam a aproximadamente $2,3 \%$ do valor da produção manufatureira britânica. Em 1760 ápice das importaçóes lusas oriundas da Grã Bretanha - tal proporção havia subido para 4,4\% $\%^{83}$. Dito de outra forma, do aumento, estimado em $£ 8$ milhóes, do valor da produção industrial inglesa entre 1700 e 1760 , cerca de $£ 680$ mil (ou 8,5\%) corresponderam à demanda exercida pelo mercado de Portugal (incluindo suas colônias) ${ }^{84}$. Trata-se de parcela não desprezível da produção manufatureira britânica, sem dúvida ${ }^{85}$.

Contudo, tal percentagem não deve ser tomada como evidência prima facie da importância do mercado português para a industrialização da Grã Bretanha. De fato, são muitos os reparos feitos na literatura ao argumento geral ligando exportaçôes europeias de manufaturados e industrialização. Em primeiro lugar, note-se que afirmar que o aumento das exportaçóes foi importante para a industrialização e o crescimento econômico europeu não explica porque tal demanda externa beneficiou mais a Grã Bretanha do que outros países (como a França, por exemplo, onde o comércio cresceu mais até do que na Grã Bretanha no século XVIII, atingindo valores até superiores). Isso sugere que a Grã Bretanha possuía melhores condiçôes de oferta para atender a esta demanda maior; sendo este o caso, o comércio exterior não explicaria a industrialização ${ }^{86}$.

Joel Mokyr ressalta, ainda, a dificuldade em se estabelecer a priori a direçâo da causalidade entre as variáveis "exportaçôes" e "industrialização" 87 . No período em apreço, lembra, não apenas a demanda maior do setor externo estimulou o aumento da oferta inglesa, como também a produção industrial maior permitiu, via ganhos de produtividade (e queda de preços), crescimento da demanda externa. Em outras palavras, as exportaçóes maiores, simultaneamente, causaram e foram determinadas pelo crescimento da produção industrial ${ }^{88}$. Além disso, do ponto de vista teórico, não se deve (como parece ser o caso, explicita ou implicitamente, em muitos autores) tomar todas as exportaçóes de um país como um ganho líquido para ele. Isso somente é verdade no caso de os fatores de produção (capital, trabalho, recursos naturais) naquela economia estarem previamente ociosos ${ }^{89}$. Em outras palavras, há que se ter em conta o custo de oportunidade daqueles fatores, vale dizer, a renda resultante das atividades que deixaram de ser feitas para que tais fatores fossem canalizados para o setor exportador ${ }^{90}$.

Em um cenário de pleno emprego (ou próximo dele), os ganhos proporcionados pelo comércio são aqueles ressaltados pela teoria econômica tradicional, podendo ser classificados em "estáticos" e "dinâmicos". No primeiro caso, têm-se os chamados ganhos de especialização, que resultam em benefícios para ambas as partes envolvidas (sejam elas países, indivíduos, regiôes). Os ganhos ditos "dinâmicos", por sua vez, dizem respeito a acréscimos de produtividade decorrentes de efeitos de escala - e são difíceis de ser mensurados. 
Os estudos empíricos que procuram medir os efeitos (estáticos) do comércio internacional sobre o bem-estar costumam chegar a resultados que indicam ganhos modestos ${ }^{91}$. Já no tocante aos ganhos de natureza dinâmica, isto é, aqueles aumentos de produtividade obteníveis em unidades fabris que se tornaram maiores, em parte, para atender à demanda externa, Deirdre McCloskey tampouco se mostra otimista ${ }^{92}$. A partir de um exercício contrafactual, a autora estima que, caso o setor têxtil algodoeiro inglês fosse reduzido à metade como decorrência da perda dos mercados estrangeiros, tal fato implicaria reduzir em 5 p.p. (isto é, de $100 \%$ para 95\%) a taxa de crescimento estimada da renda per capita britânica entre 1780-186093. Portanto, os ganhos "dinâmicos" do comércio exterior para a Grã Bretanha tampouco podem ser considerados extraordinários ${ }^{94}$.

Em suma, seja de uma perspectiva teórica como empírica, há sérias dúvidas quanto à importância do comércio exterior para a industrialização europeia no século XVIII.

Essa conclusão geral não é tão surpreendente assim, tendo em vista que antes do terceiro quartel do século XIX (e, portanto, antes do início do laissez faire, combinado aos avanços nos transportes e comunicaçóes - ferrovias, navios a vapor, telégrafo etc.) a economia europeia era relativamente fechada. Como resultado, os preços internos de bens e fatores (e, com isso, os sinais para a alocaçáo de recursos entre os diversos setores da economia) eram determinados, essencialmente, pela oferta e a demanda dentro da Europa. Foi apenas a partir da primeira onda de globalização e a maior integração dos mercados mundiais que os preços de bens e fatores na Europa passaram a ser determinados pela demanda e oferta global. Nestes termos, somente após a Revoluçáo Industrial o comércio exterior passou a ser decisivo para a economia europeia ${ }^{95}$.

Tal resultado se aplica tanto de forma geral como na experiência da Grã Bretanha em particular e não há porque imaginar que teria sido diferente no caso específico do comércio anglo-português. Se assim for, a importância do mercado de Portugal e suas possessóes para a industrialização britânica - que, conforme visto, está na base do "modelo" do Antigo Sistema Colonial - também deve ser colocada em dúvida.

\section{Conclusões}

O influente "modelo" do Antigo Sistema Colonial repousa sobre três elementos principais, logicamente encadeados, a saber: a noção de exclusivo comercial nas relaçóes entre Portugal e o Brasil colonial; (a partir daí) a extração de "superlucros"; e a transferência destes para a Inglaterra, onde teriam ajudado na acumulação de capital que precedeu a Revolução Industrial.

Nas seçóes 1 e 2, argumentou-se que há fortes evidências de que o exclusivo colonial foi mais exceção do que norma nas relaçôes Portugal-Brasil. Prova disso, há também muitos indícios de que os excedentes extraídos de tal relação não foram particularmente extraordinários, sendo, provavelmente, errada a noção de que a exploração colonial teria proporcionado "superlucros". Já na terceira seção do artigo procurou-se mostrar que o papel das relaçóes anglo-portuguesas - tanto no que toca à possibilidade de captura, pelos britânicos, de parte dos excedentes coloniais lusos, como da ampliaçáo de mercados consumidores para seus manufaturados - deve ser vista com reservas.

Os adeptos do "modelo", como dito, postulam uma relação "triangular" ligando Portugal, o Brasil e a Grã Bretanha que, em última instância, teria favorecido a industrialização desta última. Contudo, em momento algum conseguem demonstrar empiricamente a intricada cadeia de nexos que mediaria tais relaçóes de causa e efeito. Sendo assim, ao final, tem-se um argumento do tipo post hoc, ergo propter hoc ("depois disto, logo, por causa disto"). Ou seja, dado que a industrialização da Inglaterra se deu em contexto de relaçóes comerciais e diplomáticas anglo-portuguesas que em alguns casos (na seqüência do tratado de 1654, em particular) se mostraram claramente desfavoráveis a Portugal conclui-se que a industrialização decorreu (ou, ao menos, beneficiou-se) de tal relação. Trata-se de raciocínio falacioso. 
Mas, se assim é, por que o "modelo" até hoje exerce tanta influência sobre a historiografia? Porque, na forma como é enunciado, ele é, de fato, muito persuasivo e, de certa maneira, as partes parecem se encaixar. Examinando-o com mais cuidado, porém, percebe-se que, essencialmente, ele segue uma lógica do seguinte tipo: Uma vez que:

1) o Brasil foi organizado como colônia de exploração e foi submetido ao exclusivo colonial com a metrópole portuguesa; e

2) desta relação extraíram-se "superlucros"; e

3) a Inglaterra mantinha relaçóes comerciais privilegiadas com Portugal, que lhe abriram a possibilidade de capturar a maior parte dos (super?)lucros derivados do comércio português com o Brasil; e

4) a Revolução Industrial ocorreu na Inglaterra; e

5) (segundo Marx) a acumulação primitiva foi indispensável para o advento do capitalismo e teve no colonialismo uma de suas manifestaçôes,

conclui-se que a dinâmica do Antigo Sistema Colonial operou no sentido de permitir a industrialização europeia ${ }^{96}$.

Entendido nestes termos, o "modelo" parece, sim, consistente - mas apenas no caso de se considerar como fato comprovado que (3) permitiu, efetivamente, a transferência de lucros excedentes do comércio Brasil-Portugal para a Inglaterra e que, operando em conjunto com (2) e (5) - que, como argumentado, por si sós, são proposiçôes questionáveis -, contribuiu de forma decisiva (foi "pré-requisito") para (4) - a Revolução Industrial. E isso o "modelo", decididamente, não consegue demonstrar, pois a evidência histórica e a teoria econômica não estão do seu lado.

Note-se a enorme semelhança na estrutura lógica do "modelo" e aquela que serve de base para os argumentos de Immanuel Wallerstein em suas críticas a Patrick O’Brien e Leandro Prados de la Escosura:

Imaginemos a hipótese de que a economia mundial capitalista tivesse sido construída sobre um eixo de divisão de trabalho que envolvesse uma extensa transferência de mais valia da periferia para o centro. E imaginemos ainda a hipótese de que, como consequência, surgisse uma estrutura política de estados relativamente fortes no centro que, no entanto, estivessem em constante competição entre si, como acontece com indivíduos capitalistas. Poderia acontecer entấo que a estrutura beneficiasse a "Europa como um todo" sem necessariamente beneficiar os que seriam os perdedores relativos entre os estados competidores neste centro. Para verificar a veracidade desta hipótese, não é tấo necessário analisar cada país separadamente, especialmente em termos de variáveis econômicas. É possível que as variáveis políticas expliquem primariamente a distribuição da mais valia entre os estados do centro e que, portanto, respondam pelo seu desempenho econômico. ${ }^{97}$

Wallerstein - a exemplo dos adeptos do "modelo" do Antigo Sistema Colonial - também parte da hipótese da existência de enormes excedentes, que são transferidos da "periferia" para o "centro" do "sistema-mundo" (e, pela via política, são re-distribuídos no interior do "centro"). E, tal como seus pares no Brasil, tampouco oferece comprovação factual mais sólida para seu argumento ${ }^{98}$.

Para concluir, no caso do "modelo" do Antigo Sistema Colonial, tudo indica que, da mesma forma que o esquema de Wallerstein, ele é, essencialmente, axiomático, isto é, somente "fecha" caso se considere que (2), (3) e (5) sejam, sem sombra de dúvida, verdadeiros. Contudo, na falta de mais e melhores evidências empíricas que indiquem minimamente:

i. A existência de superlucros no comércio luso-brasileiro;

ii. os mecanismos precisos que permitiram a canalização de parte substantiva destes superlucros para a Grã Bretanha; e

iii. a forma como tais recursos contribuíram para industrialização britânica (e, eventualmente, a Revolução Industrial), 
ele permanecerá sendo, no fundo, uma proposição teórica com baixo poder explicativo da dinâmica de funcionamento da economia do Brasil-colônia e sua relação com a Europa (ou, mais amplamente, o mundo atlântico) no início da Era Moderna.

Ao que parece, ciente do caráter, essencialmente, teórico do "modelo" (do Antigo Sistema Colonial), Novais já afirmava:

Nunca será demais insistir que esse esquema interpretativo não se propóe como sucedâneo dos estudos monográficos que devem iluminar cada processo específico; nem como modelo adaptável a toda e qualquer circunstância. Antes se apresenta como marco para as reflexões, ponto de partida e não de chegada. ${ }^{99}$

$\mathrm{Na}$ prática, porém, passadas quatro décadas, a tarefa de testar o 'esquema' de Novais à luz das evidências empíricas ficou a cargo, exclusivamente, de autores que procuraram qualificá-lo ${ }^{100}$. Diante desta constatação, resta esperar que os adeptos deste esquema explicativo procurem dotá-lo de sustentação factual mais robusta. Afinal, não está claro porque o ônus da prova (empírica) deva recair apenas sobre as interpretações alternativas ao "modelo" do Antigo Sistema Colonial.

\section{Notas}

${ }^{1}$ Ver NOVAIS, Fernando. Portugal e Brasil na crise do antigo sistema colonial (1777-1808). São Paulo: Hucitec, 1979. O artigo irá se referir, na esmagadora maioria dos casos, a este trabalho de Novais, por ser a obra "fundadora" do "modelo" do Antigo Sistema Colonial e aquela que, direta ou indiretamente, baliza a historiografia moderna sobre o tema.

${ }^{2}$ Ver PRADO JUNIOR, Caio. PRADO JUNIOR, Caio. Formaçấo do Brasil contemporâneo: colônia. 7.ed. São Paulo: Brasiliense, 1963.

${ }^{3}$ NOVAIS, Fernando. Aproximaçōes: estudos de história e historiografia. São Paulo: Cosac Naify, 2005, p. 391-2.

${ }^{4}$ No caso português, objeto do estudo do autor, o recorte cronológico é delimitado pelo fim do período pombalino e a abertura dos portos brasileiros, ou seja, 1777-1808.

${ }^{5}$ Neste sentido, ele não irá dialogar (ao menos, diretamente) com a importante discussão acerca do papel relativo do mercado interno colonial comparativamente ao setor exportador, revigorada por FRAGOSO, João Luís Ribeiro. Homens de grossa aventura: acumulação e hierarquia na praça mercantil do Rio de Janeiro (1790-1830). Rio de Janeiro: Arquivo Nacional, 1992; FRAGOSO, João Luís Ribeiro e FLORENTINO, Manolo Garcia. O arcaísmo como projeto: mercado atlântico, sociedade agrária e elite mercantil no Rio de Janeiro, c. 1790-c.1840. 3.ed. Rio de Janeiro: 7Letras, 1998.; e, mais recentemente - propondo um revisionismo extremo -, CALDEIRA Jorge. História do Brasil com empreendedores. São Paulo: Mameluco, 2009. Ao leitor interessado nesta controvérsia, recomenda-se a excelente resenha realizada por MAGALHÂES, Diogo Franco. O reinventar da colônia: um balanço das interpretaçōes sobre a economia colonial brasileira. Dissertaçấo de Mestrado. Instituto de Economia/Unicamp, 2008.

${ }^{6}$ Cf. NOVAIS, Portugal e Brasil na crise do antigo sistema colonial (1777-1808), op. cit., p. 91-2.

${ }^{7}$ Para detalhes, ver REIS, Arthur Cézar Ferreira. O comércio colonial e as companhias privilegiadas. In: Holanda, Sergio Buarque de (Dir.). História geral da civilização brasileira. São Paulo: Difel, 1985. Tomo I, vol. 2. Conforme se verá mais à frente, mesmo durante o regime de frotas, Portugal se viu levado a conceder autorização à atuaçáo de comerciantes estrangeiros na sua colônia americana, como sucedido após o tratado firmado com a Inglaterra em 1654.

${ }^{8}$ Cf. NOVAIS, Fernando. Portugal e Brasil na crise do antigo sistema colonial (1777-1808), op. cit., p. 89-90.

${ }^{9}$ ALDEN, Dauril. Vicissitudes of Trade in the Portuguese Atlantic Empire during the First Half of the Eighteenth Century: a review article. The Americas, v. 32, n. 2, October 1975, p. 287 (grifo meu). No original: "Both the quantity of goods available and the prices they fetched varied drastically depending upon how recently the fleets (frotas) from Lisbon, Porto and the Atlantic wine islands had been in port. If they were delayed, prices soared 50 to $100 \%$ above customary levels, only to collapse as soon as the vessels appeared. If, as his agents frequently urged him to do, Pinheiro was able to obtain special license from the Overseas Council to send a ship with badly needed supplies which arrived before the fleets, both he and his agents stood to reap substantial profits. But if he and his associates misread the market and dispatched goods in the fleets which already contained ample supplies provided by their competitors, an overstock resulted and no one made money. In colonial times venturing in overseas trade, like investments in mines and the production of staples, was always a gamble" [Tradução Lise Sedrez].

${ }^{10}$ Esta possibilidade fora aventada por E. Hamilton, ao tratar do comércio de Portugal com o Brasil: "Apparently all Portuguese subjects were free to participate, but we do not know the extent to which formal associations or informal agreements among 
businessmen or other trading bodies limited competition". Cf. HAMILTON, Earl. The Role of Monopoly in the Overseas Expansion and Colonial Trade of Europe Before 1800. American Economic Review, vol. 38, n. 2, Papers and Proceedings of the $60^{\text {th }}$ Annual Meeting of the AEA, May 1948, p. 39.

${ }^{11}$ Tratando do período em que as companhias de comércio pombalinas atuaram no Brasil, José R. Junior afirma que “(...) quando os coloniais náo concordassem com o preço atribuído ao seu produto (açúcar, couro etc.) podiam enviar à Europa por sua conta, através dos navios da Companhia, pagando o frete e as demais despesas". Cf. RIBEIRO JÚNIOR, José. Colonização e monopólio no nordeste brasileiro. São Paulo: Hucitec, 1976. p. 90.

${ }^{12}$ A expressão está à p. 573 de FLORY, Rae \& SMITH, David Grant. Bahian Merchants and Planters in the Seventeenth and Early Eighteenth Centuries. Hispanic American Historical Review, vol. 58, n. 4, 1978.

${ }^{13}$ Ver SCHWARTZ, Stuart. Sugar Plantations in the Formation of Brazilian Society: Bahia, 1550-1835. Cambridge: Cambridge University Press, 1985, p. 196-200. Fenômeno semelhante também se verificava no Rio de Janeiro, como nota Joáo Fragoso em "A nobreza da república: notas sobre a formação da primeira elite senhorial do Rio de Janeiro (séculos XVI e XVII)" (Topoi. Revista de História, v. 1, n. 1, 2000, p. 45-122). Diante da capacidade demonstrada pelos senhores de engenho fluminenses de interferirem, através do senado, nos preços da economia das plantations, o autor conclui que "(...) o chamado pacto colonial, ao que parece, não era tão poderoso na determinação da vida dos coloniais”. Ibid., p. 85. Sobre a fixação, após intervenção da Coroa, de preços mínimos que deveriam ser pagos aos produtores de açúcar fluminenses, ver ABREU, Mauricio de Almeida. Geografia Histórica do Rio de Janeiro (1502-1700). Rio de Janeiro: Andrea Jakobsson Estúdio e Prefeitura do Município do Rio de Janeiro, 2010, vol. 2, p. 59.

${ }^{14}$ Ver, por exemplo, O Brasil nos quadros do antigo sistema colonial. In: MOTA, Carlos Guilherme (Org.). Brasil em perspectiva. 19.ed. Rio de Janeiro: Bertrand Brasil, 1990. p. 53; e ARRUDA, José Jobson de Andrade. O sentido da colônia: revisitando a crise do antigo sistema colonial no Brasil (1780-1830). In: TENGARRINHA, José (Org.). História de Portugal. Bauru: Edusc, 2000. p. 168.

${ }^{15}$ Cf. NOVAIS, Fernando. Portugal e Brasil na crise do antigo sistema colonial (1777-1808), op. cit., p. 90-2; Arruda, José J. O Brasil no comércio colonial. São Paulo: Ática, 1980, p. 69-70; e ARRUDA, José J. A produção económica. In: Maria Beatriz Nizza da Silva (Coord.). O Império Luso-Brasileiro, 1750-1822. Lisboa: Editorial Estampa, 1986 (vol. VIII da Nova história da expansáo portuguesa, dir. de Joel Serrão e A. H. Oliveira Marques), p. 166-8. Conforme ressaltado por J. R. do Amaral Lapa, a estes dois canais deve-se adicionar o comércio intercolonial, realizado entre a América portuguesa e colônias de outras naçôes, ou dentro do Império luso. Este último caso incluiria não apenas as trocas ligando Brasil e África, como também as possessóes de Portugal no Oriente e o Brasil, pela via da escala, na Bahia, de navios da Carreira das Índias. Ver LAPA, José R. do Amaral. O Antigo Sistema Colonial. São Paulo: Brasiliense, 1982. Para o comércio com o Oriente, ver $A$ Bahia e a Carreira da Índia. São Paulo: Companhia Editora Nacional, 1968; e RUSSELL-WOOD, A. J. R. Centros e periferias no mundo luso-brasileiro, 1500-1808. Revista Brasileira de História, vol. 18, n. 36, 1998.

${ }^{16}$ Cf. NOVAIS, Fernando. Portugal e Brasil na crise do antigo sistema colonial (1777-1808), op. cit., p. 90-1; e ARRUDA, José J. A produção econômica, op. cit., p. 163-8. A noção de "superlucros" será discutida mais detalhadamente na próxima seção.

${ }^{17}$ Para uma análise das economias mercantilistas como fundadas na busca e extração dessas rendas de monopólio, ver EKELUND Jr., Robert B. \& TOLLISON, Robert D. Politicized Economies: monarchy, monopoly, and mercantilism. College Station, TX: Texas A\&M University Press, 1997; e Idem, Mercantilism as a Rent-Seeking Society: economic regulation in historical perspective. College Station, TX: Texas A\&M University Press, 1981.

${ }^{18}$ É instrutivo, neste sentido, o contraste realizado por J. Lockhart e S. Schwartz entre um império espanhol fechado a comerciantes de outros países e no qual a navegação com as colônias era canalizada através de um único porto (Sevilha), e o caso português, muito mais poroso, em que navios estrangeiros faziam a maior parte do transporte entre colônia e metrópole. $\mathrm{O}$ primeiro caso aproximar-se-ia muito mais do arquétipo do modelo de Pacto Colonial enfatizado na literatura do que o caso português. Ver LOCKHART, James \& SCHWARTZ, Stuart B. Early Latin America: a history of colonial Spanish America and Brazil. Cambridge: Cambridge University Press, 1983, p. 224-5. Este ponto já fora notado por NOVAIS, Fernando. O Brasil nos quadros do antigo sistema colonial. In: MOTA, Carlos Guilherme (Org.). Brasil em perspectiva. 19.ed. Rio de Janeiro: Bertrand Brasil, 1990, p. 55.

${ }^{19}$ A incapacidade de Portugal exercer efetivamente o exclusivo refletir-se-ia, adicionalmente, no desenvolvimento de uma elite comercial colonial nos portos brasileiros gozando de grande autonomia em relação à sua congênere portuguesa. Para o caso do Rio de Janeiro na primeira metade do séc. XVIII, ver SAMPAIO, Antonio Carlos Jucá. Famílias e negócios: a formação da comunidade mercantil carioca na primeira metade do Setecentos. In: FRAGOSO, João Luís R.; ALMEIDA, Carla Maria C. de; SAMPAIO, Antonio Carlos Jucá de (Orgs.) Conquistadores e negociantes: histórias de elites no Antigo Regime nos trópicos, séculos XVI a XVIII. Rio de Janeiro: Nova Fronteira, 2001.

${ }^{20}$ A discussão a ser feita nesta seção se refere ao aspecto "microeconômico" da lucratividade do comércio colonial. Em outras palavras, as taxas de lucro obtidas por indivíduos ou empresas monopolísticas no comércio colonial. Tal discussão é distinta - ainda que, obviamente, relacionada - daquela que envolve os custos e benefícios da atividade colonial para as metrópoles europeias da época (a dimensão "macroeconômica”). Esta última é objeto da próxima seção do artigo. 
${ }^{21}$ Cf. NOVAIS, Fernando. Portugal e Brasil na crise do antigo sistema colonial (1777-1808), op. cit., p. 89.

${ }^{22}$ Os argumentos apresentados neste e no próximo parágrafo baseiam-se, em grande medida, em DAUDIN, Guillaume. Comment Calculer les Profits de la Traite? Mimeo, 2002. Disponível em

<http://spire.sciences-po.fr/hdl:/2441/691/resources/cfi-art-gd-outremer2002draft.pdf>

${ }^{23}$ Um problema adicional ressaltado por Daudin diz respeito a questôes de amostragem (viés de seleção), Uma vez que chegou às mãos dos historiadores modernos apenas uma pequena percentagem dos registros das operaçóes coloniais realizadas por comerciantes metropolitanos (no caso do tráfico de escravos, menos de $5 \%$ do total). Sendo assim, os estudos empíricos que têm por base tal documentação podem chegar a taxas de lucro que não seriam representativas da lucratividade média do setor como um todo.

${ }^{24}$ DAUDIN, Guillaume. Comment Calculer les Profits de la Traite? Op. cit., p. 22 e segs.

${ }^{25}$ Um exemplo simples dado pelo autor (p. 147-8) deixa claro o grau de diferença de resultados a que se pode chegar, caso se desconsidere a cronologia dos retornos sobre o investimento realizado pelos comerciantes da época: um investimento inicial de 100 libras que produzisse 125 libras em um ano resultaria em "taxa de lucro" (taxa interna de retorno) de 25\%; caso estas mesmas 125 libras voltassem às mãos do investidor no espaço de cinco anos representariam taxa interna de retorno de apenas 4,6\%. Ver DAUDIN, Guillaume. Profitability of Slave and Long-Distance Trading in Context: the case of eighteenth-century France. Journal of Economic History, vol. 64, n. 1, March 2004, p. 144-171.

${ }^{26}$ Para o controverso debate em torno do montante e destinação final dos lucros advindos do tráfico negreiro, ver SOLOW, Barbara L. \& ENGERMAN, Stanley. British Capitalism and Caribbean Slavery: the legacy of Eric Williams. Cambridge: Cambridge University Press, 1987; SOLOW, Barbara L. Slavery and the Rise of the Atlantic System. Cambridge: Cambridge University Press, 1991; BLACKBURN, Robin. The Making of New World Slavery: from the Baroque to the Modern. Londres: Verso, 1997; RICHARDSON, David. The Ending of the British Slave Trade in 1807: the economic context. Parliamentary History, vol. 26, Supplement, 2007, p. 127-140; e a Apresentação, de David Brion Davis, à nova edição de DRESCHER, Seymour. Econocide: British slavery in the era of Abolition. 2.ed. Chapel Hill, NC: University of North Carolina Press, 2010. Para um balanço desta extensa literatura, ver MORGAN, Kenneth. Slavery, Atlantic Trade and the British Economy, 16601800. Cambridge: Cambridge University Press, 2000, cap. 3.

${ }^{27}$ Ver $O$ Brasil no comércio colonial. São Paulo: Ática, 1980.

${ }^{28}$ Ibid., p. 348-50 e 566-7.

${ }^{29}$ Ibid., p. 570.

${ }^{30}$ ALDEN, ALDEN, Dauril. Vicissitudes of Trade in the Portuguese Atlantic Empire during the First Half of the Eighteenth Century: a review article, op. cit., p. 287, ao comentar as atividades do comerciante lisboeta Francisco Pinheiro, parece incorrer em erro semelhante ao de Arruda, quando afirma que “(...) Pinheiro's net profits from the sales of durables and perishables appear to have averaged about 20\%”. Trata-se, muito provavelmente, da margem bruta (e não de taxa de retorno sobre o capital investido) cujos componentes aparecem indicados em parte das tabelas do volume I de LISANTI, Luis. Negócios Coloniais: uma correspondência comercial do século XVIII. Brasília: Ministério da Fazenda; São Paulo: Visão, 1973. Tais valores, por sua vez, correspondem à dedução, do "valor de carregação (das mercadorias) em Lisboa", de um conjunto limitado de despesas incorridas por Pinheiro. Neste caso, aplicam-se as mesmas críticas feitas aos cálculos de Arruda.

${ }^{31}$ Curiosamente - e na ausência de posição explícita ao contrário -, parece haver aceitação generalizada na literatura dos números de Arruda como boa aproximação para a noção de "superlucros". Assim, mesmo o historiador português Jorge Pedreira, conhecido crítico da noção de "crise" do Antigo Sistema Colonial, ao tratar dos superlucros, afirma: "A diferença entre o preço de importação em Portugal e o preço de reexportação seria a medida dessa exploração, que espoliava os brasileiros dos lucros derivados da exportaçáo de seus produtos. Admitamos que assim fosse (...)”. Mas, à luz do que se argumentou acima, pode-se, mesmo, admiti-lo? Ver PEDREIRA, Jorge M. Economia e política na explicação da independência do Brasil. In: MALERBA, Jurandir (Org.). A independência brasileira. Rio de Janeiro: Ed. FGV, 2006. p. 71.

${ }^{32}$ Ver VRIES, Jan de \& WOUDE, Ad van der. The First Modern Economy: success, failure, and perseverance of the Dutch economy, 1500-1815. Cambridge: Cambridge University Press, 1997, Tabela 10.5a, p. 442. No caso das companhias de comércio inglesa e francesa atuantes nas Índias Orientais, também foram observadas margens brutas (isto é, uma relação entre os preços de compra na Ásia e revenda na Europa) da mesma ordem de grandeza, vale dizer, de 1,5:1 a 3:1. Ver VRIES, Jan de. The Limits of Globalization in the Early Modern World. Economic History Review, vol. 63, n. 3, August 2010, p. 710-733, Tabela 2, p. 723.

${ }^{33}$ Ver VRIES, Jan de \& WOUDE, Ad van der. The First Modern Economy: success, failure, and perseverance of the Dutch economy, 1500-1815, op. cit., Tabela 10.6, p. 445. Neste caso, a rentabilidade é dada pela relação entre os dividendos distribuídos pela VOC a seus acionistas e o preço médio de suas açóes na Bolsa. A diferença deste indicador de rentabilidade para os lucros efetivos é dada pelos lucros retidos, re-investidos na empresa.

${ }^{34}$ E que, no caso do comércio da noz moscada nas ilhas de Banda, praticou o exclusivo mais "puro sangue" (e violento) possível, envolvendo manter as plantaçóes e as ilhas sob permanente vigilância, controlando militarmente o escoamento da noz moscada e punindo com morte o contrabando daquela especiaria. 
35 Com base na documentação referente a 65 expediçôes comerciais nas quais investiu Bertrand de Coeuvre, mercador de Nantes atuante no comércio colonial na segunda metade do séc. XVIII.

${ }^{36}$ A razão para esta combinação de retornos mais elevados (porém, não extraordinários) em meio a risco e maturidade mais baixos no caso dos investimentos no comércio colonial seria a existência de barreiras à entrada naquela atividade. Estas, por sua vez, seriam dadas por exigências de riqueza inicial elevada para se ingressar na atividade, combinadas com a importância de redes de negociantes que limitavam o ingresso de "estranhos" naquele ramo de atividade. Cf. DAUDIN, Guillaume. Profitability of Slave and Long-Distance Trading in Context: the case of eighteenth-century France, op. cit., p. 166-8.

${ }^{37}$ Para um argumento semelhante, ver McCLOSKEY, Deirdre. Bourgeois Dignity: why economics can't explain the modern world. Chicago: University of Chicago Press, 2010, cap. 18.

${ }^{38}$ Cf. NOVAIS, Portugal e Brasil na crise do antigo sistema colonial (1777-1808), op. cit., p. 114.

${ }^{39}$ A esses, Novais acrescentaria um outro objetivo da exploração colonial ultramarina, qual seja, o de complementar a economia europeia através do fornecimento de produtos “(...) de que ela carecia e provendo matérias primas para a sua produção industrial (...)”. Ibid., p. 112. O papel das colônias enquanto fornecedoras de matérias primas para a industrialização europeia, porém, não é enfatizado na discussão subseqüente feita pelo autor.

${ }^{40}$ Juntamente com o movimento dos cercamentos dos campos na Inglaterra e a dívida pública, por exemplo. Ver MARX, Karl. O Capital: crítica da economia política. 2.ed. Sáo Paulo: Nova Cultural, 1985, vol. 1, tomo 2, cap. XXIV e, na mesma linha, DOBB, Maurice. Studies in the Development of Capitalism. Londres: Routledge, 1947, cap. V.

${ }^{41}$ Cf. McCLOSKEY, Deirdre. Bourgeois Dignity: why economics can't explain the modern world, op. cit., p. 155.

42 Ibid., p. 129. Compare-se a relação semente-rendimento (seed-to-yield ratio) do trigo à época (1:4) com os 1:40/1:50 obteníveis modernamente.

${ }^{43}$ Ibid., p. 132. Como, ao final, foi a Grã Bretanha que se industrializou primeiro, McCloskey termina por fazer coro com o medievalista Michael Postan, para quem os baixos níveis de investimento observados na Inglaterra náo seriam produto de baixa poupança, mas de poucas oportunidades, naquele país, de realizarem-se investimentos produtivos.

${ }^{44}$ Para este último ponto, ver QUINN, Stephen. Money, Finance and Capital Markets. In: FLOUD, Roderick \& JOHSON, Paul (Eds.). The Cambridge Economic History of Modern Britain (vol. 1 "Industrialisation, 1700-1860"). Cambridge: Cambridge University Press, 2004, p. 160. Os baixos requisitos de capital de longo prazo nas primeiras fábricas foram observados em trabalho pioneiro de POLLARD, Sidney. Fixed Capital in the Industrial Revolution in Britain. Journal of Economic History, vol. 24, n. 3, September 1964, p. 299-314. Contudo, P. Richardson chega a números maiores que os de Pollard no estudo de dois casos no setor têxtil algodoeiro. Ver RICHARDSON, Philip. The Structure of Capital during the Industrial Revolution Revisited: two case studies from the cotton textile industry. Economic History Review, vol. 42, n. 4, November 1989, p. 484-503.

${ }^{45}$ Um indício adicional de que a Inglaterra não sofria de escassez de capital à época é dado pelo nível da taxa de juros (menos de 5\%, contra 2-3\% na também rica em capital Holanda) que passou a prevalecer a partir do final do século XVII. Ver HOMER, Sidney \& SYLLA, Richard. A History of Interest Rates. 4.ed. Hoboken, NJ: Rutgers University Press, 2005, p. 160-3.

${ }^{46}$ Neste sentido, repetem argumento de SIDERI Sandro. Trade and Power: Informal Colonialism in Anglo-Portuguese Relations. Roterdam: Universitaire Pers Rotterdam, 1970.

${ }^{47}$ Para o teor dos três primeiros, ver MAURO, Frédéric. Portugal, o Brasil e o Atlântico, 1570-1670. Lisboa: Editorial Estampa, 1989, vol. II, p. 213-7. Os elementos de continuidade e mudança entre os diferentes tratados são analisados em COSTA, Leonor Freire. Da Restauração a Methuen: ruptura e continuidade. In: CARDOSO, José Luís et al. O Tratado de Methuen (1703). Lisboa: Horizonte, 2003.

${ }^{48}$ Ver SIDERI Sandro. Trade and Power: Informal Colonialism in Anglo-Portuguese Relations, op. cit., p. 20.

${ }^{49}$ Ver COSTA, Leonor Freire. Relaçóes económicas com o exterior. In: LAINS, Pedro e Álvaro SILVA, Ferreira da (Orgs.). História Económica de Portugal, 1700-2000 (vol. I “O século XVIII”). Lisboa: Imprensa de Ciências Sociais, 2005, p. 266.

${ }^{50}$ Ver Leitura e interpretação do Tratado de Methuen. In: CARDOSO, José Luís et al. O Tratado de Methuen (1703). Lisboa: Horizonte, 2003, p. 21-22. Na prática, portanto, a alíquota cobrada sobre importaçóes inglesas seria inferior àquela paga por comerciantes do próprio Reino. Ver SIDERI Sandro. Trade and Power: Informal Colonialism in Anglo-Portuguese Relations, op. cit., p. 20.

${ }^{51}$ Ibid., p. 21. As condiçôes draconianas do Tratado de 1654 foram asseguradas a partir do envio, por Cromwell, de uma esquadra a Portugal em 1656, a fim de debelar resistências locais (Ibid., p. 20). Ainda segundo o autor, o teto de 23\%, contido na cláusula secreta, aplicava-se a todas as exportaçóes inglesas, embora fosse dirigido, sobretudo, aos panos de lã, que constituíam o principal item de exportaçóes para Portugal. Ibid., p. 21.

52 Ibid., p. 22.

${ }^{53}$ Cf. COSTA, Leonor Freire. Da Restauração a Methuen: ruptura e continuidade, op. cit., p. 42. 
${ }^{54}$ Ver ISRAEL, Jonathan. The Emerging Empire: the Continental perspective, 1650-1713. In: CANNY, Nicholas (Ed.) The Oxford History of the British Empire (vol. I "The Origins of Empire. British Overseas Enterprise to the Close of the Seventeenth Century"). Oxford: Oxford University Press, 2001, p. 423.

${ }^{55}$ Ver FRANCIS, A. David. John Methuen and the Anglo-Portuguese Treaties of 1703. The Historical Journal, vol. 3, n. 2, 1960, p. 103-124.

${ }^{56}$ Do lado português, também se esperava obter, com a vitória da Grande Aliança e conseqüente indicação do pretendente austríaco ao trono espanhol, conquistas territoriais nas regióes da Estremadura e Galícia, além da colônia do Sacramento, ao sul da América portuguesa. Ver MONTEIRO, Nuno Gonçalo F. Identificação da política setecentista. Notas sobre Portugal no início do período joanino. Análise Social, vol. XXXV, n. 157, 2001, p. 961-987.

${ }^{57}$ Para um balanço recente, ver CARDOSO, José Luís. Leitura e interpretação do Tratado de Methuen. In: CARDOSO, José Luís et al. O Tratado de Methuen (1703). Lisboa: Horizonte, 2003.

${ }^{58}$ Foram promulgadas pragmáticas em 1677, 1686, 1688, 1698 e 1702. Ver FRANCIS, A. David. John Methuen and the Anglo-Portuguese Treaties of 1703, op. cit., p. 105, nota 8.

${ }^{59}$ Ver PINTO, Virgílio Noya. O ouro brasileiro e o comércio anglo-português. São Paulo: Cia. Editora Nacional, 1979 , p. 37.

${ }^{60}$ Ver MARIUTTI, Eduardo B. Colonialismo, imperialismo e o desenvolvimento econômico europeu. São Paulo: Aderaldo \& Rothschild, 2009, p. 287.

${ }^{61}$ As críticas ao que denominou de "obsessão com a extração de excedentes coloniais", sua eventual importância para a industrialização europeia, bem como à noção wallersteiniana de "sistema econômico mundial" já aparecem em CARDOSO, Ciro Flamarion S. As concepçóes acerca do "Sistema Econômico Mundial" e do "Antigo Sistema Colonial”: a preocupação obsessiva com a "extração do excedente". In: LAPA, José Roberto do Amaral (Org.). Modos de produção e realidade brasileira. Petrópolis: Vozes, 1980. Paul Bairoch e Patrick O’Brien estimam que os lucros obtidos por empresários ingleses no comércio colonial como um todo corresponderam a não mais que 6\% da formação bruta de capital fixo no país entre 1700 e 1780 (Bairoch) ou, no máximo, 15\% entre 1750-1850 (O’Brien). Ver BAIROCH, Paul. Commerce International et Genèse de la Révolution Industrielle Anglaise. Annales. Économies, Sociétés, Civilizations, ano 28, n. 2, 1973, p. 541-571; e O'BRIEN, Patrick. European Economic Development: the contribution of the periphery. Economic History Review, vol. 35, n. 1, February 1982, p. 1-17.

${ }^{62}$ Cf. COSTA, Leonor Freire. Da Restauração a Methuen: ruptura e continuidade, op. cit., p. 41.

${ }^{63}$ Conforme nota CARDOSO, José Luís. Política económica. In: LAINS, Pedro e SILVA, Álvaro Ferreira da (Orgs.). História Económica de Portugal, 1700-2000 (vol. I “O século XVIII”). Lisboa: Imprensa de Ciências Sociais, 2005, p. 347; e PEDREIRA, Jorge M. Diplomacia, manufacturas e desenvolvimento económico. Em torno do mito de Methuen. In: CARDOSO, José Luís et al. O Tratado de Methuen (1703), op. cit., p. 131.

${ }^{64}$ Ibid., p. 149-51.

${ }^{65}$ Tanto é assim que novas pragmáticas foram promulgadas em 1749, ou que, ainda, o marquês de Pombal pôde levar a termo um conjunto de medidas industrializantes no terceiro quarto do século XVIII, isto é, na vigência dos dispositivos acordados em 1703 - e no contexto de declínio das relaçóes comerciais anglo-portuguesas. Ver CARDOSO, José Luís. Política econômica, op. cit.; e PEDREIRA, Jorge M. Diplomacia, manufacturas e desenvolvimento económico. Em torno do mito de Methuen, op. cit., p. 150.

${ }^{66}$ Ibid.

${ }^{67}$ Cf. FRANCIS, A. David. John Methuen and the Anglo-Portuguese Treaties of 1703, op. cit., p. 122.

${ }^{68}$ Ver DUGUID, Paul. The Making of Methuen: the commercial Treaty in the English imagination. História - Revista da Faculdade de Letras do Porto, série III, vol. 4, 2003, p. 9-36.

${ }^{69}$ Dados em FISHER, H. E. S. De Methuen a Pombal: o comércio anglo-português de 1700 a 1770. Lisboa: Gradiva, 1984, Apêndice 1. Para este crescimento, deve ter contribuído a prática seguida pela Inglaterra, segundo relatos de um contemporâneo (D. Luís da Cunha, conhecido opositor dos termos do Tratado de 1703), de taxar os vinhos portugueses com alíquota $1 / 2$ inferior à cobrada sobre os concorrentes franceses, isto é, abaixo do teto de $1 / 3$ permitido pelo Tratado. Ver PEDREIRA, Jorge M. Economia e política na explicação da independência do Brasil, op. cit., p. 146, nota 64.

${ }^{70} \mathrm{O}$ déficit acumulado por Portugal ao longo do século XVIII em seu comércio com a Grã Bretanha ascenderia a $£$ 45,6 milhóes. Ver SERRÃO, José Vicente. O quadro económico. In: MATTOSO, José (Dir.). História de Portugal (vol. 4 "O Antigo Regime, 1620-1807”). Lisboa: Estampa, 1998, p. 98.

${ }^{71}$ Citado em COSTA, Leonor Freire. Relaçôes económicas com o exterior, op. cit., p. 267.

72 Ibid., p. 294-5.

${ }^{73}$ Para tanto, também podem ter contribuído tratados comerciais firmados por Portugal com a Holanda (1705) e França (1713) em bases semelhantes às acordadas com a Inglaterra em 1703. Ver FISHER, H. E. S. De Methuen a Pombal: o comércio anglo-português de 1700 a 1770, op. cit., p. 61, nota 127 . Note-se que náo se procura aqui menosprezar os efeitos 
do tratado de Methuen sobre o comércio exterior português. Dentre outras conseqüências, por exemplo, é notório que o tratado deu origem a uma situaçáo na primeira metade do século XVIII em que a importância de Portugal para o comércio exterior da Inglaterra (seja como fonte de importaçóes ou destino de exportaçóes) era, comparativamente, muito menor que o peso da Inglaterra nas relaçóes comerciais portuguesas. Daí decorreu uma dependência muito maior de Portugal em relaçáo àquele parceiro do que vice versa. Ver SERRÃO, José Vicente. O quadro económico, op. cit., p. 98.

${ }^{74}$ Ver CARDOSO, José Luís. Política económica, op. cit., p. 354; PEDREIRA, Jorge M. Diplomacia, manufacturas e desenvolvimento económico. Em torno do mito de Methuen, op. cit., p. 151-2; e SERRÃO, José Vicente. O quadro económico, op. cit., p. 94-9.

75 Adicionalmente, há indícios de que, como decorrência das descobertas de ouro no Brasil, Portugal tenha sofrido na primeira metade do século XVIII o que se convencionou denominar "doença holandesa” (Dutch disease). Resumidamente, trata-se do caso em que a descoberta de vastas quantidades de recursos naturais (ou um aumento súbito no preço de recursos existentes) em determinado país, via apreciação da taxa de câmbio real, leva a encolhimento do seu setor manufatureiro. Na prática, a partir deste novo nível de câmbio real, o setor industrial (mais precisamente, o conjunto do setor produtor de bens comercializáveis) experimentaria perda de competitividade e, com isso, retração, cedendo espaço à produção de bens nãocomercializáveis (serviços, sobretudo). O resultado final da "doença” seria, portanto, uma deterioração da balança comercial do país no qual se deu a descoberta daquele recurso (ou, no caso em questão, na metrópole). O trabalho inaugural da literatura sobre a Dutch disease é CORDEN, W. Max. The Exchange Rate, Monetary Policy and North Sea Oil: the economic theory of the squeeze of tradables. Oxford Economic Papers, vol. 33, Supplement, 1981, p. 23-46. Para o caso de Portugal no século XVIII (embora o próprio autor não se refira explicitamente à "doença holandesa" ou à literatura relevante), ver MOURÃO, Paulo Reis. As exportações portuguesas entre 1717 e 1770: os efeitos do pombalismo através de uma discussão econométrica. Economia Aplicada, vol. 13, n. 2, 2009, p. 279-298. A Espanha também teria sido vítima da "doença” na segunda metade do século XVI, segundo DRELICHMAN, Mauricio. The Curse of Moctezuma: American silver and the Dutch disease. Explorations in Economic History, vol. 42, Issue 3, July 2005, p. 349-380. Agradeço a Samuel Pessoa por chamar minha atenção para a possibilidade de, durante o ciclo do ouro brasileiro, Portugal ter vivido um episódio histórico de "doença holandesa" avant la lettre.

${ }^{76}$ Não obstante, note-se que, em paralelo, as exportaçóes britânicas de metais preciosos (bullion) para a Holanda na primeira metade do século XVIII alcançaram mais de $£ 1$ milhão anuais, refletindo o déficit estrutural da Europa Ocidental no comércio com o Báltico, dominado pelos Estados Gerais. Ver ORMROD, David. The Rise of Commercial Empires: England and the Netherlands in the Age of Mercantilism, 1650-1770. Cambridge: Cambridge University Press, 2003, p. 82-3. O padrão-ouro de jure só seria adotado na Inglaterra em 1816. Para detalhes, ver REDISH, Angela. The Evolution of the Gold Standard in England. Journal of Economic History, vol. L, n. 4, December 1990, p. 789-805.

${ }^{77}$ FURTADO, Celso. Formação Econômica do Brasil. 10.ed. São Paulo: Cia. Editora Nacional, 1970, p. 83 e PINTO, Virgílio Noya. O ouro brasileiro e o comércio anglo-português, op. cit., p. 333, são exceçóes. Para as atividades do Banco da Inglaterra no período, ver MATHIAS, Peter. The First Industrial Nation: an economic history of Britain, 1700-1914. 2.ed. Londres: Methuen, 1983, cap. 5. P. Rousseau, por sua vez, encontra evidência estatística de causalidade entre a maior monetização da economia inglesa (proporcionada pelas operaçóes de redesconto do Banco da Inglaterra) e a produção industrial daquele país, entre 1720 e 1845 . Ver ROUSSEAU, Peter L. Historical Perspectives on Financial Development and Economic Growth. The Federal Reserve Bank of Saint Louis Review, July/August 2003, p. 81-106. Por fim, J. Clapham traz referência explícita ao papel vital desempenhado pelo ouro brasileiro ("the Rand of the mid-eighteenth century") nas operaçóes do Banco da Inglaterra no período. Ver CLAPHAM, John. The Bank of England: a history. Cambridge: Cambridge University Press, 1945. vol. I, p. 220 e 235.

${ }^{78}$ A associação entre mercados externos (inclusive, coloniais) e a industrialização europeia tem uma longa tradição na literatura anglo-saxã tratando da Revolução Industrial. Exemplos disto são, dentre outros, DEANE, Phyllis e COLE, W. A. British Economic Growth, 1688-1959. 2.ed. Cambridge: Cambridge University Press, 1967; DEANE, Phyllis. A Revolução Industrial. 2.ed. Rio de Janeiro: Zahar,1973; HOBSBAWM, Eric J. Da revolução industrial inglesa ao imperialismo. Rio de Janeiro: Forense Universitária, 1979; CUENCA ESTEBAN, Javier. The Rising Share of British Industrial Exports in Industrial Output, 1700-1851. Journal of Economic History, vol. 57, n. 4, December 1997, p. 879-906; e FINDLAY, Ronald e O'ROURKE, Kevin H. Power and Plenty: Trade, War, and the World Economy in the Second Millennium. Princeton e Oxford: Princeton University Press, 2007. Para uma ótima resenha, ver INIKORI, Joseph E. Africans and the Industrial Revolution in England: a study of international trade and economic development. Cambridge: Cambridge University Press, 2002, cap. 2.

79 Dados de produção industrial de N. Crafts, citados em ENGERMAN, Stanley L. Mercantilism and Overseas Trade, 1700-1800. In: FLOUD, Roderick \& McCLOSKEY, Deirdre (Eds.) The Economic History of Britain Since 1700 (vol 1: 1700-1860). 2.ed. Cambridge: Cambridge University Press, 1994; valor da produção da indústria lanífera retirado de DEANE, Phyllis. The Output of the British Woolen Industry in the Eighteenth Century. Journal of Economic History, vol. 17, n. 2, June 1957, p. 207-223.

${ }^{80}$ Ibid., p. 220.

${ }^{81}$ Ver o Apêndice em DAVIS, Ralph. English Foreign Trade, 1700-1774. Economic History Review, vol. 15, n. 2, 1962, p. 
285-309. A taxa média anual de crescimento das exportaçóes de artigos de lá foi de $0,9 \%$ entre 1697 e 1760 , contra uma média de 1,6\% anuais para o conjunto das exportaçôes britânicas no mesmo período. Ver CROUZET, François. Toward an Export Economy: British exports during the Industrial Revolution. Explorations in Economic History, vol. 17, n. 1, January 1980, p. 48-93. Tal como no caso da produção industrial, os grupos que ganharam mais espaço dentre as exportaçôes manufaturadas britânicas ao longo dos primeiros três quartos do século foram os artigos de metal e "miscelâneas"; no último quartel, dispararam as exportaçóes de artigos de algodão.

${ }^{82}$ Ver FISHER, H. E. S. De Methuen a Pombal: o comércio anglo-português de 1700 a 1770, op. cit.

${ }^{83} \mathrm{O}$ valor da produção industrial inglesa em 1700 foi estimado em $£ 15,6$ milhóes e as importaçóes portuguesas de artigos de lã somaram, em média, $£ 358$ mil entre 1700 e 1704 . Em 1760, tais valores foram, respectivamente, de $£ 23,6$ milhôes e $£ 1,086$ milhão. Dados de produção industrial estimados por N. Crafts (e citados em ENGERMAN, Stanley L. Mercantilism and Overseas Trade, 1700-1800, op. cit.); importaçóes portuguesas de artigos de lá da Grã Bretanha em FISHER, H. E. S. De Methuen a Pombal: o comércio anglo-português de 1700 a 1770, op. cit.

${ }^{84}$ Segundo N. Crafts, a proporção da produção industrial da Grã Bretanha destinada às exportaçôes teria recuado de $24 \%$ em 1700 para 22\% em 1760. Em outras palavras, justamente no período convencionalmente identificado como do início da Revolução Industrial, os mercados externos teriam apresentado importância menor para o setor industrial britânico. Cuenca Esteban (The Rising Share of British Industrial Exports in Industrial Output, 1700-1851), por sua vez, estima que a importância das exportaçóes aumentou em igual período, de $22 \%$ do valor da produção industrial britânica para $31 \%$.

${ }^{85}$ Ainda que ela viesse a decair sensivelmente na segunda metade do século XVIII, à medida que as importaçóes portuguesas de manufaturados diminuíam e a produção industrial expandia na Grã Bretanha.

${ }^{86}$ Para este ponto, ver MOKYR, Joel. Demand vs. Supply in the Industrial Revolution. Journal of Economic History, vol. 37 , n. 4, December 1977, p. 981-1008.

${ }^{87}$ Ibid.

${ }^{88}$ Hatton et al. concluem que, estatisticamente, o sentido da causalidade foi da maior oferta inglesa para maiores exportaçóes. Ver HATTON, Timothy J., John S. LYONS e S. E. SATCHELL. Eighteenth-Century British Trade: Homespun or Empire Made? Explorations in Economic History, vol. 20, issue 2, April 1983, p. 163-182.

${ }^{89}$ Como notam, entre outros, ENGERMAN, Stanley L. Mercantilism and Overseas Trade, 1700-1800, op. cit.; MOKYR, Joel. Editor's Introduction. In: MOKYR, Joel (Ed.). 2.ed. The British Industrial Revolution: an economic perspective. Boulder, CO: Westview Press, 1999; e McCLOSKEY, Deirdre. Bourgeois Dignity: why economics can't explain the modern world, op. cit.

90 1780-1860: a survey. In: FLOUD, R. \& McCLOSKEY, D. (Eds.). The Economic History of Britain Since 1700 (vol. 1 “1700-1860”). 2.ed. Cambridge: Cambridge University Press, 1994, p. 255-7. Na prática, porém, é possível que, no século XVIII, muitos dos recursos empregados na produçáo têxtil de lá - o principal setor de exportaçóes manufatureiras inglesas à época - envolvessem trabalhadores rurais parcialmente ociosos. Sendo assim, os ganhos resultantes da exportação destes artigos podem ter sido maiores do que McCloskey afirma. Para este ponto, ver MOKYR, Joel. Editor's Introduction, $o p$. cit., p. 71.

${ }^{91}$ Ver McCLOSKEY, Deirdre. Bourgeois Dignity: why economics can't explain the modern world, op. cit. Ainda assim, o fato permanece que tais ganhos seráo tanto maiores quanto maior for a diferença de dotaçáo de fatores de cada parte envolvida. Em se tratando do comércio colonial, em que as metrópoles trocavam manufaturados por alimentos e matérias-primas que não podiam ser produzidos na Europa (exceto a custos muito elevados), é provável que os ganhos estáticos fossem menos insignificantes do que a autora sugere.

92 Ibid.

${ }^{93}$ Ibid., p. 219-21.

${ }^{94}$ Cabe ressaltar que tal exercício desconsidera os impactos resultantes da aplicação alternativa daqueles recursos, que sairiam do setor têxtil para outra atividade, em busca de emprego. Neste caso, as perdas seriam ainda menores que o indicado por McCloskey.

${ }^{95}$ Para uma elaboração deste argumento, ver O'ROURKE, Kevin e WILLIAMSON, Jeffrey G. From Malthus to Ohlin: trade, industrialization and distribution since 1500. Journal of Economic Growth, vol. 10, n. 1, 2005, p. 5-34. Agradeço a Samuel Pessoa por insistir comigo na importância deste ponto.

${ }^{96}$ Aqui, os adeptos do "modelo" não se preocupam em distinguir países que mantiveram até o século XX um vigoroso comércio colonial e se industrializaram tardiamente - caso da Holanda - daqueles que se industrializaram pouco após a Inglaterra e sequer possuíam colônias, a exemplo da Bélgica e Suíça. Ao final, tratam a Revolução Industrial britânica, na passagem do século XVIII para o XIX, como um fenômeno "europeu".

${ }^{97}$ Ver WALLERSTEIN, Immanuel. Commentary on Papers for Session A1, XIIth International Economic History Congress. Theme: the Economic Consequences of Empires (1492-1989). Disponível em <http://fbc.binghamton.edu/ 
iwechis.htm>, p. 3. No original: "Suppose we hypothesize that the capitalist world-economy was constructed around an axial division of labor which involved extensive transfer of surplus value from periphery to core. And suppose we hypothesize that there was created as a consequence a political structure of relatively strong states in the core which, however, were in constant competition with each other, as were individual capitalists. It might follow that the structure benefited 'Europe as a whole' without necessarily benefiting the relative losers among the competing states in the core. To see if this were true, it is of limited use to analyze each country separately, especially in the terms of economic variables. It might be political variables that accounted primarily for distribution of the surplus among the states in the core, and therefore accounted for their economic performance" [Tradução Lise Sedrez]. Ver, também, O’BRIEN, Patrick \& PRADOS DE LA ESCOSURA, Leandro. The Costs and Benefits for Europeans from their Empires Overseas. Revista de Historia Económica, año 16, n. 1, Invierno 1998, p. 29-89.

${ }^{98}$ Como o próprio autor reconhece, é muito difícil testar empiricamente o cenário por ele descrito. Sendo assim, seu argumento permanece sendo apenas uma conjectura útil para a consistência de seu modelo. Ver WALLERSTEIN, Immanuel. Commentary on Papers for Session A1, XIIth International Economic History Congress, op. cit.

${ }^{99}$ Ver As dimensões da Independência. In: MOTA, Carlos Guilherme (Org.). 1822: Dimensôes. São Paulo: Perspectiva, 1972 , p. 24. ${ }^{100}$ A exemplo de João Luís Ribeiro Fragoso (Homens de grossa aventura: acumulação e hierarquia na praça mercantil do Rio de Janeiro (1790-1830), op. cit.; e "A nobreza da república: notas sobre a formaçáo da primeira elite senhorial do Rio de Janeiro. Séculos XVI e XVII”, Topoi. Revista de História, v. 1, n. 1, 2000, p. 45-122.); FRAGOSO, João Luís Ribeiro e FLORENTINO, Manolo Garcia. O arcaísmo como projeto: mercado atlântico, sociedade agrária e elite mercantil no Rio de Janeiro, c. 1790c.1840, op. cit.; SAMPAIO, Antonio Carlos Jucá de. Na encruzilhada do Império: hierarquias sociais e conjunturas econômicas no Rio de Janeiro (c.1650-c.1750). Rio de Janeiro: Arquivo Nacional, 2003; e CALDEIRA, Jorge. O banqueiro do sertão. Sáo Paulo: Mameluco, 2006.

\section{Referências bibliográficas}

ABREU, Mauricio de Almeida. Geografia Histórica do Rio de Janeiro (1502-1700). Rio de Janeiro: Andrea Jakobsson Estúdio e Prefeitura do Município do Rio de Janeiro, 2010. 2 vols.

ALDEN, Dauril. Vicissitudes of Trade in the Portuguese Atlantic Empire during the First Half of the Eighteenth Century: a review article. The Americas, vol. 32, n. 2, October 1975, p. 282-291.

ARRUDA, José Jobson de Andrade. O sentido da colônia: revisitando a crise do antigo sistema colonial no Brasil (1780-1830). In: TENGARRINHA, José (Org.). História de Portugal. Bauru: Edusc, 2000.

. A produção económica. In: Maria Beatriz Nizza da Silva (Coord.). O Império Luso-Brasileiro, 1750-1822. Lisboa: Editorial Estampa, 1986. Vol. VIII da Nova história da expansão portuguesa, dir. de Joel Serrão e A. H. Oliveira Marques.

O Brasil no comércio colonial. São Paulo: Ática, 1980.

BAIROCH, Paul. Economics and World History: myths and paradoxes. Chicago: University of Chicago Press, 1983.

Commerce International et Genèse de la Révolution Industrielle Anglaise. Annales.

Économies, Sociétés, Civilizations, v. 28, n. 2, 1973, p. 541-571.

BLACKBURN, Robin. The Making of New World Slavery: from the Baroque to the Modern. Londres: Verso, 1997.

CALDEIRA Jorge. História do Brasil com empreendedores. São Paulo: Mameluco, 2009.

O banqueiro do sertão. São Paulo: Mameluco, 2006.

CARDOSO, Ciro Flamarion S. As concepçôes acerca do "Sistema Econômico Mundial" e do "Antigo Sistema Colonial": a preocupação obsessiva com a "extração do excedente". In: LAPA, José Roberto do Amaral (Org.). Modos de produção e realidade brasileira. Petrópolis: Vozes, 1980.

CARDOSO, José Luís. Política económica. In: LAINS, Pedro e SILVA, Álvaro Ferreira da (Orgs.). História Económica de Portugal, 1700-2000. Lisboa: Imprensa de Ciências Sociais, 2005. Vol. I “O século XVIII”. 
Leitura e interpretação do Tratado de Methuen. In: CARDOSO, José Luís et al. O Tratado de Methuen (1703). Lisboa: Horizonte, 2003.

CLAPHAM, John. The Bank of England: a history. Cambridge: Cambridge University Press, 1945.

CORDEN, W. Max. The Exchange Rate, Monetary Policy and North Sea Oil: the economic theory of the squeeze of tradables. Oxford Economic Papers, vol. 33, Supplement, 1981, p. 23-46.

COSTA, Leonor Freire. Relações económicas com o exterior. In: LAINS, Pedro e Álvaro SILVA, Ferreira da (Orgs.). História Económica de Portugal, 1700-2000. Lisboa: Imprensa de Ciências Sociais, 2005. Vol. I "O século XVIII".

. Da Restauração a Methuen: ruptura e continuidade. In: CARDOSO, José Luís et al. O Tratado de Methuen (1703). Lisboa: Horizonte, 2003.

CROUZET, François. Toward an Export Economy: British exports during the Industrial Revolution. Explorations in Economic History, vol. 17, n. 1, January 1980, p. 48-93.

CUENCA ESTEBAN, Javier. The Rising Share of British Industrial Exports in Industrial Output, 1700-1851. Journal of Economic History, vol. 57, n. 4, December 1997, p. 879-906.

DAUDIN, Guillaume. Profitability of Slave and Long-Distance Trading in Context: the case of eighteenth-century France. Journal of Economic History, vol. 64, n. 1, March 2004, p. 144-171.

Comment Calculer les Profits de la Traite? Mimeo, 2002. Disponível em <http://spire.sciences-po.fr/hdl:/2441/691/resources/cfi-art-gd-outremer2002draft.pdf>

DAVIS, Ralph. The British Industrial Revolution and British Overseas Trade. Leicester: Leicester University Press, 1979.

. English Foreign Trade, 1700-1774. Economic History Review, vol. 15, n. 2, 1962, p. 285-309.

DEANE, Phyllis. A Revolução Industrial. 2ed. Rio de Janeiro: Zahar: 1973.

. The Output of the British Woolen Industry in the Eighteenth Century. Journal of Economic History, vol. 17, n. 2, June 1957, p. 207-223.

DEANE, Phyllis \& COLE, W. A. British Economic Growth, 1688-1959. Cambridge: Cambridge University Press, 2a ed., 1967.

DOBB, Maurice. Studies in the Development of Capitalism. Londres: Routledge, 1947.

DRELICHMAN, Mauricio. The Curse of Moctezuma: American silver and the Dutch disease. Explorations in Economic History, vol. 42, Issue 3, July 2005, p. 349-380.

DRESCHER, Seymour. Econocide: British slavery in the era of Abolition. 2.ed. Chapel Hill, NC: University of North Carolina Press, 2010.

DUGUID, Paul. The Making of Methuen: the commercial Treaty in the English imagination. História. Revista da Faculdade de Letras do Porto, série III, vol. 4, 2003, p. 9-36.

EKELUND Jr., Robert B. \& TOLLISON, Robert D. Politicized Economies: monarchy, monopoly, and mercantilism. College Station, TX: Texas A\&M University Press, 1997.

Mercantilism as a Rent-Seeking Society: economic regulation in historical perspective. College Station, TX: Texas A\&M University Press, 1981.

ENGERMAN, Stanley L. Mercantilism and Overseas Trade, 1700-1800. In: FLOUD, Roderick 
\& McCLOSKEY, Deirdre (Eds.) The Economic History of Britain Since 1700. 2.ed. Cambridge: Cambridge University Press, 1994. Vol 1 “1700-1860”.

FINDLAY, Ronald \& O'ROURKE, Kevin H. Power and Plenty: Trade, War, and the World Economy in the Second Millennium. Princeton e Oxford: Princeton University Press, 2007.

FISHER, H. E. S. De Methuen a Pombal: o comércio anglo-português de 1700 a 1770. Lisboa: Gradiva, 1984.

FLORY, Rae \& SMITH, David Grant. Bahian Merchants and Planters in the Seventeenth and Early Eighteenth Centuries. Hispanic American Historical Review, vol. 58, n. 4, 1978, p. 571-594.

FRAGOSO, João Luís Ribeiro. A formação da economia colonial no Rio de Janeiro e de sua primeira elite senhorial (séculos XVI e XVII). In: FRAGOSO, João Luís R., BICALHO, Maria Fernanda, GOUVÊA, Maria de Fátima (Orgs.) O Antigo Regime nos Trópicos: a dinâmica imperial portuguesa (séculos XVI-XVIII). Rio de Janeiro: Civilização Brasileira, 2001.

A nobreza da república: notas sobre a formação da primeira elite senhorial do Rio de Janeiro (séculos XVI e XVII). Topoi. Revista de História, v. 1, n. 1, 2000, p. 45-122.

Homens de grossa aventura: acumulação e hierarquia na praça mercantil do Rio de Janeiro (1790-1830). Rio de Janeiro: Arquivo Nacional, 1992.

FRAGOSO, João Luís Ribeiro e FLORENTINO, Manolo Garcia. O arcaísmo como projeto: mercado atlântico, sociedade agrária e elite mercantil no Rio de Janeiro, c. 1790-c.1840. 3.ed. Rio de Janeiro: 7Letras, 1998.

FRANCIS, A. David. John Methuen and the Anglo-Portuguese Treaties of 1703. The Historical Journal, vol. 3, n. 2, 1960, p. 103-124.

FURTADO, Celso. Formação econômica do Brasil. 10ed. São Paulo: Cia. Editora Nacional, 1970.

HAMILTON, Earl. The Role of Monopoly in the Overseas Expansion and Colonial Trade of Europe Before 1800. American Economic Review, vol. 38, n. 2, Papers and Proceedings of the $60^{\text {th }}$ Annual Meeting of the AEA, May 1948, p. 33-53.

HARLEY, Knick C. Trade: discovery, mercantilism and technology. In: FLOUD, Roderick \& JOHSON, Paul (Eds.). The Cambridge Economic History of Modern Britain (vol. 1 "Industrialisation, 1700-1860"). Cambridge: Cambridge University Press, 2004.

HATTON, Timothy J., LYONS, John S. \& SATCHELL, S. E. Eighteenth-Century British Trade: Homespun or Empire Made? Explorations in Economic History, vol. 20, Issue 2, April 1983, p. 163-182.

HOBSBAWM, Eric J. Da revolução industrial inglesa ao imperialismo. Rio de Janeiro: Forense Universitária, 1979.

HOMER, Sidney \& SYLLA, Richard. A History of Interest Rates. 4.ed. Hoboken, NJ: Rutgers University Press, 2005.

INIKORI, Joseph E. Africans and the Industrial Revolution in England: a study of international trade and economic development. Cambridge: Cambridge University Press, 2002.

ISRAEL, Jonathan. The Emerging Empire: the Continental perspective, 1650-1713. In: CANNY, Nicholas (Ed.) The Oxford History of the British Empire. Oxford: Oxford University Press, 2001. Vol. I "The Origins of Empire. British Overseas Enterprise to the Close of the Seventeenth Century".

LAPA, José Roberto do Amaral. O antigo sistema colonial. São Paulo: Brasiliense, 1982. . A Bahia e a Carreira da Índia. São Paulo: Companhia Editora Nacional, 1968. 
LISANTI, Luis. Negócios coloniais: uma correspondência comercial do século XVIII. Brasília: Ministério da Fazenda; São Paulo: Visão, 1973.

LOCKHART, James \& SCHWARTZ, Stuart B. Early Latin America: a history of colonial Spanish America and Brazil. Cambridge: Cambridge University Press, 1983.

MAGALHÃES, Diogo Franco. O reinventar da colônia: um balanço das interpretaçôes sobre a economia colonial brasileira. Dissertação de Mestrado, Instituto de Economia/Unicamp, 2008.

MARIUTTI, Eduardo B. Colonialismo, imperialismo e o desenvolvimento econômico europeu. São Paulo: Aderaldo \& Rothschild, 2009.

MARX, Karl. O Capital: critica da economia política. 2.ed. São Paulo: Nova Cultural, 1985 (coleção Os Economistas).

MATHIAS, Peter. The First Industrial Nation: an economic history of Britain, 1700-1914. 2.ed. Londres: Methuen, 1983.

MAURO, Frédéric. Portugal, o Brasil e o Atlântico, 1570-1670. Lisboa: Editorial Estampa, 1989. 2 vols. McCLOSKEY, Deirdre. Bourgeois Dignity: why economics can't explain the modern world. Chicago: University of Chicago Press, 2010.

1780-1860: a survey. In: FLOUD, R. \& McCLOSKEY, D. (Eds.). The Economic History of Britain Since 1700. 2.ed. Cambridge: Cambridge University Press, 1994. Vol. 1 "1700-1860".

MOKYR, Joel. The Enlightened Economy: an economic history of Britain, 1700-1850. New Haven; Londres: Yale University Press, 2009.

. Editor's Introduction. In: MOKYR, Joel (Ed.). 2.ed. The British Industrial Revolution: an economic perspective. Boulder, CO: Westview Press, 1999.

Demand vs. Supply in the Industrial Revolution. Journal of Economic History, vol. 37, n. 4, December 1977, p. 981-1008.

MONTEIRO, Nuno Gonçalo F. Identificação da política setecentista. Notas sobre Portugal no início do período joanino. Análise Social, vol. XXXV, n. 157, 2001, p. 961-987.

MORGAN, Kenneth. Slavery, Atlantic Trade and the British Economy, 1660-1800. Cambridge: Cambridge University Press, 2000.

MOURÃO, Paulo Reis. As exportaçóes portuguesas entre 1717 e 1770: os efeitos do pombalismo através de uma discussão econométrica. Economia Aplicada, vol. 13, n. 2, 2009, p. 279-298.

NOVAIS, Fernando. Aproximaçôes: estudos de história e historiografia. São Paulo: Cosac Naify, 2005.

. O Brasil nos quadros do antigo sistema colonial. In: MOTA, Carlos Guilherme (Org.). Brasil em perspectiva. 19.ed. Rio de Janeiro: Bertrand Brasil, 1990.

. Portugal e Brasil na crise do antigo sistema colonial (1777-1808). São Paulo: Hucitec, 1979.

. As dimensões da Independência. In: MOTA, Carlos Guilherme (Org.). 1822: Dimensóes.

São Paulo: Perspectiva, 1972.

O'BRIEN, Patrick. European Economic Development: the contribution of the periphery. Economic History Review, vol. 35, n. 1, February 1982, p. 1-17.

. European Economic Development: a reply. Economic History Review, vol. 36, n. 4,

November 1983, p. 584-5. 
O'BRIEN, Patrick \& PRADOS DE LA ESCOSURA, Leandro. The Costs and Benefits for Europeans from their Empires Overseas. Revista de Historia Económica, año 16, n. 1, Invierno 1998, p. 29-89.

O'ROURKE, Kevin e WILLIAMSON, Jeffrey G. From Malthus to Ohlin: trade, industrialization and distribution since 1500. Journal of Economic Growth, vol. 10, n. 1, 2005, p. 5-34.

ORMROD, David. The Rise of Commercial Empires: England and the Netherlands in the Age of Mercantilism, 1650-1770. Cambridge: Cambridge University Press, 2003.

PEDREIRA, Jorge M. Economia e política na explicação da independência do Brasil. In: MALERBA, Jurandir (Org.). A independência brasileira. Rio de Janeiro: Ed. FGV, 2006.

Negócio, capitalismo, riqueza e acumulação: os negociantes de Lisboa (1750-1820).

Tempo, vol. 8, n. 15, dezembro de 2003, p. 37-69.

Diplomacia, manufacturas e desenvolvimento económico. Em torno do mito de Methuen. In: CARDOSO, José Luís et al. O Tratado de Methuen (1703). Lisboa: Horizonte, 2003.

PINTO, Virgílio Noya. O ouro brasileiro e o comércio anglo-português. São Paulo: Cia. Editora Nacional, 1979.

POLLARD, Sidney. Fixed Capital in the Industrial Revolution in Britain. Journal of Economic History, vol. 24, n. 3, September 1964, p. 299-314.

PRADO JUNIOR, Caio. Formação do Brasil contemporâneo: colônia. 7.ed. São Paulo: Brasiliense, 1963.

QUINN, Stephen. Money, Finance and Capital Markets. In: FLOUD, Roderick \& JOHSON, Paul (Eds.). The Cambridge Economic History of Modern Britain. Cambridge: Cambridge University Press, 2004. Vol. 1 "Industrialisation, 1700-1860".

REIS, Arthur Cézar Ferreira. O comércio colonial e as companhias privilegiadas. In: Holanda, Sergio Buarque de (Dir.). História geral da civilização brasileira. São Paulo: Difel, 1985. Tomo I, vol. 2.

REDISH, Angela. The Evolution of the Gold Standard in England. Journal of Economic History, vol. L, n. 4, December 1990, p. 789-805.

RIBEIRO JÚNIOR, José. Colonização e monopólio no nordeste brasileiro. São Paulo: Hucitec, 1976.

RICHARDSON, David. The Ending of the British Slave Trade in 1807: the economic context. Parliamentary History, vol. 26, Supplement, 2007, p. 127-140.

RICHARDSON, Philip. The Structure of Capital during the Industrial Revolution Revisited: two case studies from the cotton textile industry. Economic History Review, vol. 42, n. 4, November 1989, p. $484-503$.

ROUSSEAU, Peter L. Historical Perspectives on Financial Development and Economic Growth. The Federal Reserve Bank of Saint Louis Review, July/August 2003, p. 81-106.

RUSSELL-WOOD, A. J. R. Centros e periferias no mundo luso-brasileiro, 1500-1808. Revista Brasileira de História, vol. 18, n. 36, 1998, p. 187-250.

SAMPAIO, Antonio Carlos Jucá de. Na encruzilhada do Império: hierarquias sociais e conjunturas econômicas no Rio de Janeiro (c.1650-c.1750). Rio de Janeiro: Arquivo Nacional, 2003.

. Famílias e negócios: a formação da comunidade mercantil carioca na primeira metade do

Setecentos. In: FRAGOSO, João Luís R.; ALMEIDA, Carla Maria C. de; SAMPAIO, Antonio Carlos Jucá de (Orgs.) Conquistadores e negociantes: histórias de elites no Antigo Regime nos trópicos, séculos XVI a XVIII. Rio de Janeiro: Nova Fronteira, 2001. 
SCHWARTZ, Stuart. Sugar Plantations in the Formation of Brazilian Society: Bahia, 1550-1835. Cambridge: Cambridge University Press, 1985.

SERRÃO, José Vicente. O quadro económico. In: MATTOSO, José (Dir.). História de Portugal. Lisboa: Estampa, 1998. Vol. 4 "O Antigo Regime, 1620-1807”.

SIDERI, Sandro. Trade and Power: Informal Colonialism in Anglo-Portuguese Relations. Roterdam: Universitaire Pers Rotterdam, 1970.

SOLOW, Barbara L. Slavery and the Rise of the Atlantic System. Cambridge: Cambridge University Press, 1991.

SOLOW, Barbara L. \& ENGERMAN, Stanley. British Capitalism and Caribbean Slavery: the legacy of Eric Williams. Cambridge: Cambridge University Press, 1987.

VRIES, Jan de. The Limits of Globalization in the Early Modern World. Economic History Review, vol. 63, n. 3, August 2010, p. 710-733.

VRIES, Jan de \& WOUDE, Ad van der. The First Modern Economy: success, failure, and perseverance of the Dutch economy, 1500-1815. Cambridge: Cambridge University Press, 1997.

WALLERSTEIN, Immanuel. Commentary on Papers for Session A1, XIIth International Economic History Congress. Theme: the Economic Consequences of Empires (1492-1989). Disponível em $<$ http://fbc.binghamton.edu/iwechis.htm>

. European Development: a comment on O’Brien. Economic History Review, vol. 36, n. 4, November 1983, p. 580-83. 